\title{
Histological characterization of denticulate palatal plates in an early Permian dissorophoid
}

\author{
Bryan M Gee ${ }^{\text {Corresp.. }}{ }^{1}$, Yara Haridy ${ }^{1}{ }^{\text {, }}$ Robert R Reisz ${ }^{1}$ \\ ${ }^{1}$ Department of Biology, University of Toronto Mississauga, Ontario, Canada \\ Corresponding Author: Bryan M Gee \\ Email address: bryan.gee@mail.utoronto.ca
}

Denticles are small, tooth-like protrusions that are commonly found on the palate of early tetrapods. Despite their widespread taxonomic occurrence and similar external morphology to marginal teeth, it has not been rigorously tested whether denticles are structurally homologous to true teeth with features such as a pulp cavity, dentine, and enamel, or if they are bony, tooth-like protrusions. Additionally, the denticles are known to occur not only on the palatal bones but also on a mosaic of small palatal plates that is thought to have covered the interpterygoid vacuities of temnospondyls through implantation in a soft tissue covering; however, these plates have never been examined beyond a simple description of their position and external morphology. Accordingly, we performed a histological analysis of these denticulate palatal plates in a dissorophoid temnospondyl in order to characterize their microanatomy and histology. The dentition on these palatal plates has been found to be homologous with true teeth on the basis of both external morphology and histological data through the identification of features such as enamel and a pulp cavity surrounded by dentine. In addition, patterns of tooth replacement and ankylosis support the hypothesis of structural homology between these tiny teeth on the palatal plates and the much larger marginal dentition. We also provide the first histological characterization of the palatal plates, including documentation of abundant Sharpey's fibres that provide a direct line of evidence to support the hypothesis of soft tissue implantation. Finally, we conducted a survey of the literature to determine the taxonomic distribution of these plates within Temnospondyli, providing a broader context for the presence of palatal plates and illustrating the importance of maintaining consistency in nomenclature. 
1 Histological characterization of denticulate palatal plates in an early Permian dissorophoid

2 Bryan M. Gee ${ }^{1}$, Yara Haridy ${ }^{1}$, Robert R. Reisz ${ }^{1}$

$3{ }^{1}$ Department of Biology, University of Toronto Mississauga, 3359 Mississauga Road,

4 Mississauga, Ontario, L5L 1C6, Canada

5

6 Corresponding author:

7 Bryan M. Gee

8

9 Corresponding email: bryan.gee@mail.utoronto.ca

10

11

12

13

14

15

16

17

18

19

20

21

22

23

24

25

26

27

28

29 
31 Abstract. Denticles are small, tooth-like protrusions that are commonly found on the palate of early tetrapods. Despite their widespread taxonomic occurrence and similar external morphology to marginal teeth, it has not been rigorously tested whether denticles are structurally homologous to true teeth with features such as a pulp cavity, dentine, and enamel, or if they are bony, toothlike protrusions. Additionally, the denticles are known to occur not only on the palatal bones but also on a mosaic of small palatal plates that is thought to have covered the interpterygoid vacuities of temnospondyls through implantation in a soft tissue covering; however, these plates have never been examined beyond a simple description of their position and external morphology. Accordingly, we performed a histological analysis of these denticulate palatal plates in a dissorophoid temnospondyl in order to characterize their microanatomy and histology. The dentition on these palatal plates has been found to be homologous with true teeth on the basis of both external morphology and histological data through the identification of features such as enamel and a pulp cavity surrounded by dentine. In addition, patterns of tooth replacement and ankylosis support the hypothesis of structural homology between these tiny teeth on the palatal plates and the much larger marginal dentition. We also provide the first histological characterization of the palatal plates, including documentation of abundant Sharpey's fibers that provide a direct line of evidence to support the hypothesis of soft tissue implantation. Finally, we conducted a survey of the literature to determine the taxonomic distribution of these plates within Temnospondyli, providing a broader context for the presence of palatal plates and illustrating the importance of maintaining consistency in nomenclature.

Introduction. Denticles are generally recognized as small, recurved tooth-like protrusions and are commonly found in high densities throughout the palatal region in Paleozoic sarcopterygians and tetrapods, including temnospondyls (Warren \& Davey, 1992). They are also known from a subset of the more derived Meosozic temnospondyls, such as the Mastodonsauridae (e.g., Welles \& Cosgriff, 1965), the Chigutisauridae (e.g, Damiani \& Warren, 1996), the Plagiosauridae (e.g., Schoch \& Witzmann, 2012), and the Rhytidosteidae (e.g., Warren \& Davey, 1992), supporting the hypothesis that the presence of denticles represents the plesiomorphic condition within Temnospondyli (Warren \& Davey, 1992). Although denticles are frequently described in the literature, they are rarely defined, nor are they exclusive to early tetrapods. The term 'denticle' is also used in reference to serrations on the teeth of various vertebrate taxa, such as theropod 
62 dinosaurs (e.g., Smith, 2005; Brink et al., 2015) and other reptiles (e.g., De Andrade et al., 2010), 63 the tooth-like scales on extant cartilaginous fishes (e.g., Serra-Pereira et al., 2008), and tooth-like 64 protrusions in the pharyngeal cavity of agnathans, placoderms, osteichthyans, and basal tetrapods 65 (e.g., Johanson \& Smith, 2005; Witzmann, 2013). The term has also been applied to structures in 66 non-vertebrate groups, such as the tooth-like protrusions found on the hinges of bivalves (e.g., Le 67 Pennec, 1980) and on the radula in various mollusks (e.g., Lowenstam, 1962), the cheliceral teeth of sparassid spiders (e.g., Jäger, 1998), and the tooth-like processes on the subcapitulum of many mites (e.g., Evans \& Till, 1979). It is even used to refer to early cytoskeletal components in Drosophila (e.g., Price et al., 2006).

In one of the few works to formally define anamniote tetrapod denticles, Bolt \& Lombard (2003), revised an earlier definition of denticles by the same authors whereby denticles are considered to be any tooth-like protrusion possessing no more than $20 \%$ of the average maximum basal diameter and / or height of adjacent marginal teeth. However, this definition is only reflective of the external morphology, and it remains relatively untested whether denticles are true teeth or if they are simply a tooth-like protrusion formed from a different tissue and a different developmental process. For example, some clades of extant amphibians possess bony protrusions known as odontoid processes that superficially resemble enlarged teeth; these are found on the mandibles and are probably used in intraspecific competition (Fabrezi \& Emerson, 2003). The only previous histological analysis of denticles in a temnospondyl is that of Bystrow (1938), who provided an exceptionally detailed description and drawings of histological sections of denticulate palatal bones of the early Triassic trematosauroid Benthosuchus. Bystrow's work provided clear and convincing evidence that the denticles in that taxon are structurally similar to the marginal dentition, but this work has been largely overlooked, perhaps due to being written in German, and further studies are needed to evaluate these findings. Denticles of extinct Paleozoic anamniotes are regularly found on the various bones of the palate, but there have also been a few documented occurrences of exceptional preservation of small denticulate palatal plates in temnospondyls that may have been attached to soft tissue coverings of the interpterygoid vacuities (e.g., Milner \& Sequeira, 1998; Witzmann \& Schoch, 2006; Fröbisch and Reisz, 2008). These differ from denticulate branchial ossifications, which occur across a wide range of anamniote tetrapods (summarized in Witzmann, 2013), including colosteids (e.g., Hook, 1983; Witzmann, 2013), temnospondyls such as branchiosaurids (e.g., Boy, 1972), 
93 micromelerpetontids (e.g., Boy, 1995); dvinosaurs (e.g., Berman, 1973; Milner, 1982;

94 Witzmann, 2004), eryopids (e.g., Boy, 1990; Witzmann, 2005), and various

95 stereospondylomorphs (e.g., Schoch, 2002, 2003, 2008; Witzmann, 2006; Damiani et al., 2009;

96 Schoch \& Witzmann, 2009), and the 'microsaur' Microbrachis (Olori, 2013). Based on

97 comparisons of these ossifications in taxa in which both palatal and branchial plates are found

98 (e.g., Onchiodon, Archegosaurus), they can be differentiated based on their position relative to

99 other cranial elements and their general morphology; branchial plates are more elongate and oval

100 in contour and feature only a single row of teeth at one edge (e.g., Boy, 1972; Witzmann, 2005 ,

101 2006, 2013). Some taxa (e.g., branchiosaurids, larval trematopids) feature isolated branchial

102 denticles that are directly attached to the ceratobranchials, rather than on small plates

103 (Witzmann, 2013), and were likely for filter feeding (Schoch, 2009). Additionally, the presence

104 of branchial plates is indicative of the retention of gill arches with open gill clefts, whether in a

105 larval form or in aquatic (paedomorphic and non-paedomorphic) adults, by virtue of their

106 association with the branchial skeleton and should not occur in mature terrestrial anamniotes.

107 Palatal plates have not been previously examined in great detail and are only briefly

108 discussed as an aside in broader descriptions by past workers. In any given publication, only a

109 handful of references comprising a subset of other temnospondyl taxa in which these plates are

110 known are provided, resulting in the perception that they are exceptionally rare. However, our

111 review of the literature indicates that they are widely preserved in many temnospondyl families,

112 and as discussed later in this paper, a diversity of nomenclatural terms used to refer to the plates

113 likely plays a significant role in their misperceived paucity. Compared to other temnospondyl

114 families, the plates are relatively well-represented within terrestrial dissorophoids, as they are

115 known in the amphibamids Pasawioops (Fröbisch \& Reisz, 2008), Platyrhinops (Carroll, 1964;

116 Clack \& Milner, 2010), and Eoscopus (Daly, 1994), in the dissorophids Cacops morrisi (Reisz,

117 Schoch, \& Anderson, 2009), Dissorophus sp. (BMG, pers. obs.), Kamacops (Gubin, 1980), and

118 Aspidosaurus binasser (Berman \& Lucas, 2003), and in the trematopids Tambachia (Sumida et

119 al., 1998), Fedexia (Berman et al., 2010), and Phonerpeton (Witzmann \& Werneburg, 2017). A

120 large number of palatal plates were also reported from "Broiliellus" hektotopos (Berman \&

121 Berman, 1975), originally described as a dissorophid, but the taxonomic affinities of this taxon

122 are in need of revision, and it is not currently considered to be a member of the family in more

123 recent phylogenetic analyses (e.g., Schoch, 2012). 
The presence of denticle-bearing plates over the large vacuities would likely have served

125 to significantly increase the overall surface area that could be used in prey capture. The paucity

126 of these plates likely resulted from their soft tissue attachment and reduced preservation potential

127 rather than real anatomical absence, particularly in forms with extensive denticle fields on the

128 palatal bones. It is possible that these plates are distributed among early tetrapods based on their

129 documented presence in a colosteid-like form (Clack et al., 2012) and perhaps even in some

130 derived sarcopterygians, as they are reported in the porolepiform Glyptolepis (Jarvik, 1972).

131 However, because the plates show a strong correlation with the large interpterygoid vacuities that

132 characterize temnospondyls, the denticulate palatal plates present in more basal taxa lacking such

133 vacuities, such as those reported around the internal opening of the spiracle and on the basal

134 plate of the parasphenoid in Eusthenopteron (Jarvik, 1954), may not be structurally or

135 developmentally homologous to those of temnospondyls.

136 In this study, we are principally interested in the characterization of the small palatal

137 plates and their denticles in early temnospondyls, with a focus on a specimen from the well-

138 known Dolese Brothers Limestone Quarry near Richards Spur, Oklahoma. The superb quality of

139 preservation of these small palatal plates and their dentition is unequalled in the fossil record,

140 allowing us to study these plates in great detail. These palatal plates provide an excellent model

141 system for studying the relationship between palatal and marginal dentition, and we propose to

142 undertake their anatomical and histological study as part of a larger project on the evolution of

143 palatal dentition. The purpose of this paper is threefold: (1) to histologically sample denticles of

144 small palatal plates in order to re-test the original findings of Bystrow (1938) that indicated

145 structural homology between denticles of the palatal bones with true teeth, (2) to histologically

146 sample, for the first time, palatal plates of a dissorophoid that are comparable to those found

147 across Temnospondyli, and (3) to discuss the phylogenetic origin and development of these

148 plates. In addition to a description of the external morphology, we also incorporate histology, an

149 informative technique for studying the internal structures and tissues. Although paleohistological

150 studies of extinct fauna are becoming an increasingly frequent component of paleontological

151 analyses, only a few have utilized amphibian teeth as the primary study structure (e.g., Bystrow,

152 1938; Schultze, 1969; Warren \& Davey, 1992; Warren \& Turner, 2005). This study provides an

153 important follow-up to the work of Bystrow to test the hypothesis of structural homology

154 between denticles and marginal teeth in temnospondyls. Finally, little attention has been directed 
155 toward the palatal plates of temnospondyls beyond a simple description, but recent work by

156 various authors regarding the function of the interpterygoid vacuities and the histological work

157 presented here permit an enhanced discussion of these ossifications. The characterization of

158 denticulate palatal plates with acrodont implantation is important for improving our

159 understanding of the dentition of temnospondyls, which has previously been restricted mostly to

160 studies of the pleurodont marginal teeth (e.g., Warren \& Davey, 1992). Denticulate palatal plates

161 have never been histologically analyzed in early tetrapods; accordingly, the histological study of

162 these structures fills a gap in the knowledge of early anamniote tetrapod dentition and their

163 inferred feeding strategies.

164

Institutional abbreviations: OMNH: Sam Noble Oklahoma Museum of Natural History,

Norman, OK, USA; ROM: Royal Ontario Museum, Toronto, ON, Canada

167

Anatomical abbreviations: ab, alveolar bone; de, dentine; en, enamel; lb, lamellar bone; ode, old dentine; pc, pulp cavity; pcd, plicidentine; spf, Sharpey's fibers; vb, lines of von Ebner; vc, vascular canal.

\section{Materials \& Methods.}

\section{Materials}

174 The sampled material consists of a small isolated block of palatal plates from an indeterminate 175 dissorophoid temnospondyl (ROM 76838, Fig. 1A-I). Plates are distributed on the top and the bottom of the block, as well as on the sides; some are articulated with adjacent plates while others are isolated. Some plates also overlie others, although this is not presumed to be the natural articulation condition. Most of the sampled plates are of the typical black coloration that results from hydrocarbon enrichment of the material during preservation at the Richards Spur locality, but several white, unenriched plates were also identified; these are of very low contrast to the lightly colored calcareous matrix and are only visible due to the presence of exposed pulp cavities infilled with a darker material. No other elements are present on the block. We make the taxonomic assignment to the Dissorophoidea on several lines of evidence: (1) among extinct anamniote tetrapods, denticulate plates are only known in temnospondyls, an observation that is likely phylogenetically correlated with the plesiomorphically large interpterygoid vacuities that 
186 characterize the clade and that are typically absent in lepospondyls, (2) of the few lepospondyls

187 with convergently large interpterygoid vacuities (e.g., the nectridean Diplocaulus and the

188 'microsaur' Hyloplesion), none are reported to have palatal plates (e.g., Bossy \& Milner, 1998;

189 Carroll, 1998), and these taxa do not occur at the fossiliferous early Permian karst deposit near

190 Richards Spur, (3) terrestrial dissorophoids are the only temnospondyls known from the locality,

191 and (4) the external morphology of the plates and the denticles on them are highly similar to

192 those of the co-occurring amphibamid Pasawioops (Fröbisch \& Reisz, 2008, Fig. 1J-L) and the

193 dissorophid Cacops (Reisz, Schoch, \& Anderson, 2009), in which the plates are articulated

194 within the skull, and to those of the dissorophid Dissorophus in which they can be reasonably

195 associated with the skull (BMG, pers. obs.). The absence of aquatic forms and early larval stages

196 of the dissorophoid taxa at the locality provides another line of evidence in support of their

197 identification as palatal plates, rather than as branchial plates. The denticles of these plates

198 feature striations, which are seen in the denticles of olsoniforms such as C. woehri and an

199 indeterminate trematopid (cf. Acheloma) from Richards Spur (BMG, pers. obs.; Fröbisch \&

200 Reisz, 2012), but not in those of Pasawioops (Fröbisch \& Reisz, 2008), a pattern that also

201 differentiates the marginal teeth of the olsoniforms from those of the amphibamids. Therefore,

202 we propose that these plates either belong to a dissorophid or a trematopid, but because of the

203 general paucity of the plates, a lack of knowledge of the relative size of the plates among the

204 dissorophoid families, and a lack of knowledge of the ontogeny of the plates, we emphasize that

205 the more specific identification is tentative and awaits further confirmation.

206 We also examined the holotype specimen of Pasawioops mayi (OMNH 73019) described

207 by Fröbisch \& Reisz (2008) that consists of a complete skull with articulated mandibles. More

208 than two dozen semi-articulated palatal plates are found in the left interpterygoid vacuity and

209 were briefly described and figured in the original description. Here we provide images of these

210 plates at high magnification for comparison with those of ROM 76838 (Fig. 1J-L). Although

211 palatal plates are known from many temnospondyl taxa, this specimen represents one of the few

212 documented occurrences of a nearly complete articulated mosaic preserved within the

213 interpterygoid vacuity.

214

215 Histological analysis 
216 ROM 76838 was imaged using a Leica DVM6 tilting microscope with LAS X software prior to

217 sampling. Individual plates were removed from the block using an air scribe and a pin vice. A

218 total of fifteen plates (all single elements save for an overlapping pair) were removed, divided

219 between several containers, and glued to a pre-poured base layer of resin under a microscope so

220 as to maximize the consistency of the orientation of the denticles for sampling. The plates were

221 then embedded in a resin of Castolite AP and an associated hardener under vacuum, and allowed

222 to set for 24 hours. The embedded plates were then separated into individual blocks that were

223 hand-ground using both a Hillquist 1010 grinding cup and a lap wheel with a 600-mesh grit to

224 remove the resin until a surface of the specimen was exposed. Each specimen was ground in a

225 step-wise fashion to create a sagittal cut of each plate in the anteroposterior axis, with repeated

226 examination under a microscope to evaluate the quality of the exposed cross-section. Because of

227 the small size of the dental plates and corresponding challenges with their sectioning, the

228 exposed plane differs slightly from an exact sagittal cut in some slides. Once an informative

229 section was exposed, it was glued to a frosted plexiglass slide using Scotch-Weld SF-100

230 cyanoacrylate glue and allowed to set for at least 30 minutes. The slides were cut to a uniform

231 height of $0.7 \mathrm{~mm}$ using a Buehler Isomet 1000 wafer blade low-speed saw and then ground on

232 the Hillquist to achieve optical clarity. Slides were polished using a 1-micron grit aluminum

233 oxide powder to remove polish lines without significant loss of material. Slides were imaged on

234 a Nikon AZ-100 microscope, with a Nikon DS-Fi2 camera attachment, using Nikon NIS-

235 Elements imaging software registered to RRR. Following the imaging of the initial slides of the

236 indeterminate dissorophoid palatal plates, it was determined that cuts in a different plane were

237 necessary to evaluate the possibility of plicidentine, and an additional six plates were isolated for

238 the same preparation. Adobe Illustrator CS6 and Adobe Photoshop CS6 were used to compile

239 figures and illustrations found within.

240

241 Description.

242 External morphology

243 The external morphology of the denticles is similar to those seen on the denticulate palatal bones

244 of temnospondyls (Fig. 1E-F, H-I). The denticles are conical at the base, as with the marginal

245 dentition of many temnospondyls, with no clear compression in one axis compared to any other.

246 Toward the crown, fluting on the teeth and the development of carinate edges become more 
247 pronounced. They are sharply recurved posteriorly and the crowns, where preserved, are oriented 248 nearly parallel to the ventral surface of the plate. It is important to note that patterns of external 249 morphology of the teeth on the palatal plates likely mirror the marginal teeth. For example, the 250 denticles of the holotype of Pasawioops (OMNH 73019), both on the palatal plates and on the 251 palatal bones, are similar to the marginal teeth in that both bear no fluting and are not carinate 252 (Fig. 1J-L). This is in contrast to the dentition of the co-occurring olsoniforms, Cacops and 253 Acheloma, both of which feature fluting and carinate edges on the marginal teeth and the denticles on the palatal bones (Reisz, Schoch, \& Anderson, 2009; Polley \& Reisz, 2011). Vacant denticle sockets are often marked by a circular depression that is surrounded by an elevated ridge. There is no clear pattern to the distribution of vacant versus filled sockets, and due to the small size of the denticles, it is likely that some were accidentally removed during preservation or during preparation. Given that the denticles are significantly more numerous than the marginal dentition, they may not have followed a similar alternating replacement pattern. The arrangement of the denticles consists of even spacing and a relatively linear orientation parallel to the anteroposterior axis.

The plates bearing the denticles are smooth on the dorsal surface (embedded in the oral mucosa) and aside from the denticle sockets on the ventral surface, lack ornamentation on both dorsal and ventral surfaces. Many feature a slightly raised lip around the margin of the entire plate. The morphology of the plates is somewhat variable, ranging from quadrilateral to trilateral contours; the significance of this variation is unclear but does not appear to be the result of postmortem damage; broken plates are clearly identifiable by the absence of a raised lip at a margin. Some plates clearly articulate with adjacent plates while others appear more isolated. This variation in plate morphology is also seen in other dissorophoids, such as Pasawioops (Fröbisch \& Reisz, 2008), Platyrhinops (Carroll, 1964; Clack \& Milner, 2010), and Cacops (Reisz,

271 Schoch, \& Anderson, 2009). In the plates sampled here, there is relatively little difference in size

272 of plates. In contrast, the articulated plates of Pasawioops vary markedly in size; some are nearly 273 twice as large as others, and many of those around the lateral margins of the vacuities are more 274 circular and significantly smaller than those located within the interior of the vacuities. There is 275 no apparent pattern of size distribution of the more interior plates. Additionally, some plates of 276 Pasawioops, although relatively large, are nearly entirely smooth, with only a handful of 277 denticles concentrated near the center. No such plates were present in ROM 76838. Finally, the 
278 holotype of Pasawioops features slender, elongate denticulate plates that overlie the cultriform

279 process; the distinct morphology of these likely relates to a presumed attachment to the process

280 rather than to a mucosa as with the plates that we sampled here.

281

\section{Histological features}

283 The denticles display essentially all of the main features that are considered to define teeth and

284 the associated peridontia in that they are characterized by the presence of a pulp cavity, vascular

285 canals, enamel, and dentine, complete with dentinal tubules and lines of von Ebner (Fig. 2-3).

286 Slight variation in some features, such as the extent of the canals and the shape of the pulp cavity

287 likely results from natural variation as well as the minor deviation from an exact sagittal cut, as

288 noted in the methods (Fig. 3). As is further discussed below, comparisons of the various dental

289 features between plates, such as enamel thickness, are not possible because of the slight variation

290 in sectioning planes.

291 A pulp cavity is present in all of the sampled plates (Fig. 2-3). The exact morphology is

292 somewhat variable due to the variation in sectioning plane. Sections in which the pulp cavity

293 appears in-filled likely represent a section that captured the innermost dentinal wall that encloses

294 the cavities. In some sections, an associated vascular canal(s) can be seen descending from the

295 pulp cavity in a near-vertical orientation perpendicular to the dorsal surface of the plate (Fig. 2-

296 3). The vascular canals are likely continuous with the dorsal surface of the plates; as with the

297 pulp cavity, variation in the morphology and degree of penetration of the canals is likely the

298 product of the plane of sectioning, as well as the three-dimensional nature of the canals. These

299 canals are the only vascularity that can be identified in the sampled plates.

300 Enamel is present on the majority of the denticles sectioned and is best visualized under

301 cross-polarized light (Fig. 2G), although it can also be identified under plane-polarized light (Fig.

302 2A) and with the use of a lambda filter (Supp. Fig 1). The enamel is acellular and highly

303 mineralized, covering the distal portion of the crown, and tapering towards but not reaching the

304 attachment site. Measuring enamel thickness at the apex of the crown for comparable purposes

305 between plates was not possible due to the aforementioned variation in sectioning.

306 Dentine is readily found in all of the sectioned dental plates with pervasive dentine

307 tubules found throughout the crown portion of the tooth, originating in the DEJ (dentine-enamel

308 junction) and terminating in the pulp cavity (Fig. 2-3). The lines of von Ebner are readily 
309 identifiable in the mineralized dentine; unfortunately, in polyphyodont taxa, these lines are not

310 informative to the age of the tooth (Erickson, 1996). The dentine-enamel junction is only

311 identifiable in some sections (e.g., Fig. 2A, F, Supp. Fig. 1A).

312 Alveolar bone is easily identifiable as the attachment tissue as it surrounds the basal edge

313 of each tooth and is distinctly separated by a reversal line from the organized lamellar bone that

314 makes up the plates (Fig. 2-3). Alveolar bone is typically fibrous or trabecular in appearance

315 (sensu LeBlanc \& Reisz, 2015) at the junction of the tooth and lamellar bone. However, it has a

316 more paralleled-fiber appearance at the base of each denticle where it forms the base of

317 attachment between the dentition and the plates, and post-mortem fractures tend to occur along

318 this junction. The extent of ankylosis varies between sections and is often incomplete (Fig. 4).

319 This cannot be attributed to a taphonomic loss of alveolar bone, as the unattached edge of the

320 tooth is undamaged, while the opposing side is ankylosed to the plate by alveolar bone. There

321 does not seem to be any pattern regarding the position of incomplete ankylosis; this can again be

322 attributed to the variable planes of section.

323 Plicidentine, defined as infoldings of the dentine into the pulp cavity at the base of the

324 tooth, has long been known in early tetrapods, being first documented in the temnospondyl

325 Mastodonsaurus by Owen (1841). It has since been found to be widespread throughout

326 numerous temnospondyls (often referred to as 'labyrinthine infoldings' in older literature), but is

327 also known in a variety of extinct and extant fishes (e.g., Schultze, 1969, 1970; Long, 1989;

328 Meunier et al., 2015). Although the classical model of dental evolution suggested a loss of

329 plicidentine in amniotes (e.g., Laurin \& Reisz, 1995), these infoldings occur in a broad number

330 of amniote groups, including ichthyosaurs (Maxwell et al, 2011b), choristoderes (Gao \& Fox,

331 1998), lepidosaurs (e.g., Kearney, Rieppel \& Wood, 2006; Maxwell et al., 2011a), captorhinids

332 (de Ricqles \& Bolt, 1983), parareptiles (e.g., Modesto \& Reisz, 2008; MacDougall et al., 2014,

333 2016), and synapsids (Brink et al., 2014). In lateral sections (Fig. 2E) of the plates and associated

334 denticles, slight infolding of the dentine can be seen at the base of the tooth, dorsal to the pulp

335 cavity, indicative of plicidentine. Although plicidentine is most easily visualized in a cross-

336 sectional profile, this proved to be a particularly difficult section to produce, and our cross-

337 sections in the dorsoventral axis could not produce clear evidence of plicidentine. We have

338 tentatively identified weak infolding in the latter profile (Fig. 2E), but additional work is required

339 to verify the presence of this infolding. 
In a single sectioned plate (Fig. 2B), a fragment of dentine can be seen imbedded within

341 the alveolar bone, neighbouring a complete tooth. This dentine fragment could have originated

342 from a broken tooth; however, it should be noted that there are no other features to indicate the

343 presence of a tooth that may have occupied this position, such as vascular canals or additional

344 alveolar bone. The alveolar bone does not extend beyond the fragment of dentine, indicating that

345 if alveolar bone had extended past the area where the fragment is imbedded, it has been either

346 eroded away, or remodelling has taken place. This dentine fragment likely indicates a position of

347 a tooth from a previous generation that has since been replaced. This fragment, coupled with the

348 varying degrees of ankylosis found in the dentition (Fig. 4), is indicative of cycles of tooth

349 development and replacement.

350 The palatal plates are composed of compact lamellar bone that lacks many features

351 commonly associated with bone, such as a diploe region, Haversian systems, and secondary

352 bone. Present in all of the plates are incremental growth marks in the lamellar bone, which are

353 identifiable by means of a variation in color associated with differential staining. The growth

354 marks do not coincide with a change in density in the bone cell lacunae, which are densely

355 distributed throughout the bone and which lack a consistent pattern in their arrangement. The

356 osteocyte lacunae are consistently oblong in outline in all specimens; they are more numerous in

357 some plates, and often found in higher density at the tooth bases (Fig. 1E) or at the distal edges

358 of the body of the plate (Fig.4A, Supp. Fig. 1D). The canaliculi cannot be visualized, although

359 this is likely the result of the relatively small scale of the plates. Primary or secondary osteons do

360 not appear to be present in any of the sectioned plates, likely indicating slow sequential

361 deposition of bone matrix. The absence of erosion cavities, as well as reversal lines (beyond

362 those found at the tooth bases), also supports the characterization of the plates as lacking

363 secondary remodelling. Also present in most of the palatal plates are abundant Sharpey's fibers,

364 which were identified on the basis of the large number of parallel striations that are oriented

365 obliquely (mainly in the dorsoventral axis) to the body of the plate (Fig. 2D, F). The Sharpey's

366 fibers cut across the growth marks found in the bone and are present throughout the length of the

367 plate, indicating that these plates were embedded in soft tissue throughout their development and

368 subsequent growth. The Sharpey's fibers appear relatively thin, but in some plates there are high-

369 density clusters of these fibers toward the curved ends of the plate. The significance of

370 differences in the relative abundance and distribution of these fibers is not apparent in the 
371 absence of a positional context. Plates located at the margins of the vacuities where they abut

372 against and possibly overlap onto the palatal bones may differ slightly in morphology compared

373 to plates located in the interior of the vacuities that are only in contact with other palatal plates.

374

375 Discussion.

376 Structural characterization of denticles

377 One of the main findings of this study is the characterization of the denticles of the palatal plates

378 of a dissorophoid temnospondyl as being structurally identical to true teeth based on the presence

379 of features such as enamel, dentine, a pulp cavity, and alveolar bone. The same features were

380 identified in the denticles of the palatal bones of Benthosuchus by Bystrow (1938:fig. 26-27),

381 supporting the hypothesis that denticles of the palatal bones and those of the palatal plates are

382 structurally homologous to each other and to true teeth, although superficial aspects of the

383 external morphology (e.g., striations, recurvature) are somewhat variable among temnospondyls,

384 as with the marginal dentition. It is important to note that Bystrow himself paralleled the palatal

385 denticles to dermal denticles of crossopterygian fishes following Gross (1935), but he did

386 identify the same typical dental tissues that we identify here in support of structural similarities.

387 An additional consideration is the definition of 'true teeth.' Reif (1982:291) previously suggested

388 that denticles should be differentiated from true teeth on the basis of their superficial formation

389 in the mesenchyme, in contrast to the deeply invaginated dental lamina of 'true teeth,' such as

390 the marginal dentition, in which replacement teeth form prior to the loss of the older teeth.

391 However, Huysseune et al. (2009:469) note that a dental lamina is not essential for tooth

392 formation, thereby negating Reif's distinction on the basis of the dental lamina and supporting

393 the homology proposed in this study.

394 The presence of abundant Sharpey's fibers provides histological evidence to support the

395 hypothesis that the plates were embedded in the soft tissue membrane covering the

396 interpterygoid vacuities. The possible identification of plicidentine may be useful for providing

397 new insights into whether the infolding is the result of phylogenetic inheritance (e.g., Schultze

398 1969, 1970; Hill, 2005), functional significance in reinforcing the tooth attachment (e.g., Scanlon

399 \& Lee, 2002; MacDougall et al., 2014), or a combination of the two (e.g., Maxwell et al., 2011c).

400 However, additional sampling is necessary to determine with greater confidence the presence of

401 plicidentine and to evaluate the degree of infolding, if present. Variable degrees of infolding 
402 between palatal denticles (either on plates or on palatal bones) and marginal dentition could be

403 reflective of the different modes of attachment (acrodont versus pleurodont) or the presumed

404 differences in modes of replacement that result from variable attachment. As we sampled a

405 dissorophoid taxon that is ecologically, phylogenetically, and temporally distinct from

406 Benthosuchus and analyzed denticles of the palatal plates rather than those of the palatal bones,

407 we believe there is good reason to infer that the structural homology of the marginal dentition

408 with denticles of both palatal bones and palatal plates is widespread throughout Temnospondyli.

410 Function

411 The function of the palatal plates in temnospondyls is likely strongly correlated with at least

412 some of the hypothesized function(s) of the interpterygoid vacuities. Several recent publications

413 have suggested a multiplicity of functions of the characteristic vacuities, none of which are

414 mutually exclusive, including: (1) a palatal buccal pump (Schoch, 2014), (2) additional muscle

415 attachment sites and increased optimization of bite force and stress distribution forces

416 (Lautenschlager, Witzmann, \& Werneburg, 2016), and (3) retraction of the eyeballs during

417 feeding and accommodation of cranial musculature (Witzmann \& Werneburg, 2017). The

418 retraction of the eyeballs in a manner similar to some extant lissamphibians to facilitate

419 swallowing of large prey items (e.g., Deban \& Wake, 2000; Levine et al., 2004) is particularly

420 appealing in the context of this paper, as the presence of a denticulate, flexible membrane would

421 likely facilitate this process. Such flexibility could only be maintained through a sheet comprised

422 of relatively small plates regardless of the overall size of the skull; in all taxa documented to

423 have these plates by our survey of the literature, the plates remain relatively small and likely

424 increase primarily in count, rather than in size, in larger taxa (Fig. 5). Independent of the

425 mobility of the vacuities, the strong recurvature of the teeth and their dense concentration,

426 forming a continuous sheet with the palatal bones, would likely have facilitated increased contact

427 with prey items and a unidirectional movement of prey toward the throat in concert with the

428 tongue. Other proposed functions have less direct bearing on the function of the plates, although

429 modeling approaches similar to those employed by Lautenschlager, Witzmann, \& Werneburg

430 (2016) that incorporate the presence of the denticulate sheet formed by the plates could be

431 helpful in assessing whether the plates influence bite force and stress distribution mechanics by

432 providing a semi-rigid covering within the vacuity. 


\section{Development}

435 Although the use of extant analogues for inferring patterns of evolution in extinct relatives has

436 often proven useful in anamniote tetrapods (e.g., Schoch, 2009; Fröbisch et al., 2010), no modern 437 analogue for palatal plates embedded in soft tissue exists in any extant terrestrial tetrapods, let 438 alone in any lissamphibians. As a result, the developmental origin and trajectory (e.g., 439 replacement of worn or damaged denticles and plates, response of the plate mosaic to the 440 expanding vacuity during ontogeny) of the plates remains somewhat unclear. It is impossible to 441 correlate these plates with any ontogenetic stage given their isolation and the lack of contextual 442 information from other taxa. Even in taxa like Pasawioops (Fröbisch \& Reisz, 2008), with plates 443 that are confidently associated with a skull, the plates are rarely known from more than one 444 specimen in which the ontogenetic maturity of the skull is constrained only relatively, rather than 445 absolutely. The most parsimonious explanation at present is that each plate represents an 446 individual ossification, originating within the covering of the interpterygoid vacuity. This could 447 account for the diversity of morphotypes seen among the plates of any one individual; naturally 448 variable rates of expansion of the plates would lead some to be slightly larger that others, and 449 also for some to acquire different shapes based on constraints imposed by surrounding plates.

\section{Replacement}

452 The replacement of the pleurodont marginal dentition found in dissorophoid temnospondyls is 453 most likely by a single tooth position, although it bears noting that this is often assumed due to 454 the relative homogeneity of tooth attachment in temnospondyls and extant lissamphibians and 455 has not been rigorously tested in extinct anamniote tetrapods (Davit-Beal et al., 2007). The 456 replacement of denticles is certainly difficult to define, considering that their attachment is 457 acrodont. While acrodonty is frequently associated with a lack of replacement in extant reptiles, 458 there is little work on the replacement of acrodont dentition of anamniote tetrapods (Bolt and 459 DeMar, 1983), Here we present the most likely mode of replacement, where the dentition found 460 on the palatal plates mirrors that of the pleurodont marginal dentition, in that a new tooth would 461 form in soft tissue, ventral to the surface of palatal plate and would eventually ankylose to the 462 plate via alveolar bone. This process of progressive ankylosis was captured in several plates 463 where the teeth were not fully ankylosed, leaving unattached edges of dentine (Fig. 4). Other 
464 teeth feature partial or 'weak' ankylosis, possibly indicating the progression of attachment.

465 Similar incomplete ankylosis in denticles of Benthosuchus was figured by Bystrow (1938:fig.

466 26-27). It is important to note that this non-symmetrical ankylosis is not an indicator of hinged

467 tooth attachment, as seen in snakes and some squamates (e.g., Patchell and Shine, 1986; Budney

468 et al., 2006). This possibility can be ruled out on the basis that we observed fully ankylosed

469 teeth; coupled with the absence of Sharpey's fibers that would otherwise indicate the presence of

470 the ligament necessary for hinged tooth attachment (Budney et al., 2006), this leads us to

471 conclude that the area lacking complete ankylosis is related to replacement of the dentition. A

472 new tooth would migrate towards an existing tooth position and eventually ankylose to the plate

473 by eroding the existing tooth, leaving only a dentine fragment such as that identified in one plate

474 (Fig. 2). However, an intermediate stage of the step-wise erosion was not captured histologically,

475 by SEM or with traditional imagining techniques in any of the plates. The same mode of tooth

476 attachment is suggested by Bystrow (1938), but it is important to note that the replacement of

477 denticles on the palatal bones is also characterized by successive deposition of new bone on top

478 of existing denticles, which is not seen in the plates.

479 It cannot be excluded that the entire plate could be replaced if it was lost due to unnatural

480 trauma, such as during feeding. Based on the apparent number of plates that would be expected

481 in an individual such as the holotype of Pasawioops, the brief vacancy created by a shed plate

482 would be unlikely to significantly impact the feeding success of the animal. There is no evidence

483 to suggest that the plates would be regularly replaced as part of the normal ontogenetic

484 trajectory, although this hypothesis cannot be excluded at present. However, it is unclear what

485 characteristics would be useful for identifying shed or newly formed plates given the

486 homogeneity and presumed comparable maturity in the sampled plates. Although the presence of

487 variably sized plates could be interpreted as evidence of a natural replacement of palatal plates

488 (assuming a positive relationship between size and maturity), other hypotheses cannot be

489 discarded. For example, the small size and circular shape of plates around the margins of the

490 vacuities in Pasawioops, a well-articulated occurrence of the plates, may be related to the

491 articulation of these plates with the palatal bones. In the plates sampled here, there was very little

492 variation in size; due to the semi-disarticulated nature of the material, it cannot be excluded that

493 smaller plates were hydrodynamically sorted and removed from this sample. Overall thickness of

494 the plate and the nature of the growth marks are also consistent throughout the sampled plates. 
495 No extant taxa form a comparable dentigerous ossification embedded in soft tissue that could be 496 analyzed to infer tooth replacement in these plates.

497

498

\section{Taxonomic perspective}

499 The plates are of little taxonomic utility, partly because their small size and soft tissue attachment result in poor preservation potential. Previous authors have suggested a widespread

501

502

503

504

505

506

507

508

509

510

511

512

513

514

515

516

517

518

519

520

521

522

523

524

525 occurrence within Temnospondyli (e.g., Clack et al., 2012), which is supported by our literature review (Fig. 6, Table 1). We have also found that they are more common than is apparent from other works that report the presence of the plates, in which they are usually compared to a semirandom handful of other taxa in which plates have been previously described (as well as being erroneously synonymized with branchial plates). Based on the current list of taxa in which the plates are known (Fig. 6; Table 1), there is no apparent correlation with adult body size, general ecology (terrestrial vs. semi-aquatic vs. aquatic), or inferred feeding ecology (e.g., insectivorous vs. piscivorous). Although it can be reasonably proposed that the plates were reduced or entirely lost along the trajectory that resulted in an absence of denticles on the palatal bones in more derived temnospondyl groups, it should be noted that the plates are found in the middle Triassic trematosaurid Trematolestes hagdorni, the late Triassic metoposaurid Metoposaurus krasiejowensis, and the early Jurassic brachyopid Siderops kehli; in all three, the palatal bones are confidently devoid of denticles (Warren \& Hutchinson, 1983; Schoch, 2006; Sulej, 2007). No denticulate palatal ossifications are reported in early lissamphibians such as the albanerpetontids, Triadobatrachus (Rage \& Rocek, 1989), or Karaurus (Ivakhnenko, 1978). If the primary function was an extension of the denticulate palatal bones for a gripping surface, then the reduction of denticles could have led to a reduction of the plates, particularly if they share a developmental trajectory. Alternatively, retention of the plates could have balanced the gradual reduction and eventual loss of the denticles on the palatal bones; this may be the condition of the three aforementioned Mesozoic taxa given the evidence for the absence of denticulate palatal bones in these derived forms. If the plates partially functioned as a semi-rigid bracing mechanism within the vacuity for stress distribution, they may have been retained in some capacity for biomechanical purposes. 
526 One of the other considerations that resulted from this study is the importance of maintaining

527 consistency in definitions and nomenclature in the literature. As noted in the introduction, the 528 definition of a 'denticle' varies widely by taxonomic group, and in the case of Drosophila, does

529 not even refer to comparable feeding structures. This is not terribly problematic as the various

530 groups for which a definition of 'denticle' exists are so distantly related as to be unlikely to occur

531 within the same study except in the context of a discussion of nomenclature as in this paper. At

532 present, we do not suggest eliminating the term as it pertains to early tetrapods in light of the

533 longstanding use of the term, as well as the continued merit of the quantitative definition of Bolt

$534 \&$ Lombard (2003). However, if additional studies of denticles in other early tetrapods support

535 our findings that the structures are teeth that are simply reduced in size (which is reasonable to

536 expect at present), the definition should be amended to reflect that they are structurally

537 equivalent to true teeth rather than tooth-like protrusions of a more ambiguous nature.

538 A more serious consideration that should be noted is that a wide variety of names exist to

539 define the denticulate plates themselves; for example, they have been referred to as

540 “denticulate(d) 'skin”" (Carroll, 1964:233; Berman \& Berman, 1975:72), "dermal plates”

541 (Fröbisch \& Reisz, 2008:1020), “dermal platelets” (Clack \& Milner, 2010:288), “dermal scales”

542 (Godfrey, Fiorillo, \& Carroll, 1987:800), "palatal platelets" (Clack et al., 2012:21), "palatal

543 plates" (Witzmann, 2006:10), and "palatal ossicles" (Schoch, 2006:34; Witzmann \& Werneburg,

544 2017:8). These nomenclatural inconsistencies likely account for the previous lack of recognition

545 of such widespread taxonomic occurrence of palatal plates as we have summarized here. Often,

546 different authors use some of these interchangeable terms to refer to different structures. For

547 example, the term 'dermal plates,' which was used by Fröbisch \& Reisz (2008:1020) to describe

548 the palatal plates of Pasawioops, was alternatively used to refer to palpebral ossifications of

549 Platyrhinops by Clack \& Milner (2010:289). Aside from the more common use of the term

550 'platelet' to refer to coagulating blood compounds, it is also not clear as to what, if any, technical

551 distinction exists between 'plate' and 'platelet,' and because the former appears to be more

552 common in the literature, it should be emphasized. The term 'ossicle' is generically defined as a

553 very small bony element, but it is most often used to more specifically refer to bones of the inner

554 ear of various vertebrates, such as mammals (e.g., Rosowski, 1992) and amphibians (e.g.,

555 Sigurdsen, 2008; Maddin \& Anderson, 2012). It has also been used to refer to denticulate

556 branchial plates (e.g., Milner, 1982:640; Schoch, 2008:91), dermal ossifications (e.g., Case, 
557 1898:519; Schoch et al. 2007:Fig. 6H), ornamented plates on the mandible (e.g., Englehorn et al. 558 2008:299) and scleral ossifications of both anamniotes (e.g., Olori, 2013:402; Schoch \& Sues, 559 2013:441) and amniotes (e.g., Sidor, 2001:1432). Additionally, the term is used with regard to 560 calcareous components of echinoderm exoskeletons (e.g., Maliva, 1989; Dickson, 2004).

561 Although the term 'plate' is fairly generic in use, as with the term 'ossicle,' we prefer the use of

562 the former because it implies a more defined morphology than the latter, which is a size-based 563 characterization. Furthermore, the problem with any nomenclature that incorporates the term 564 'dermal' is that it implies a similar formation and development to other bony plates that are 565 embedded in the skin, such as scutes and osteoderms, which are found in the connective tissue of 566 the dermis in a wide variety of extant and extinct amniotes, as well as in the dissorophid

567 temnospondyls. It is unclear whether the membranous covering of the interpterygoid vacuities to 568 which these plates were presumably attached was some form of oral mucosa (termed a 'buccal 569 mucosa' by Witzmann \& Werneburg [2017]) with a structurally homologous outer epithelial 570 layer and sub-epithelial connective tissue. If the membrane was a mucosa, then the term 'dermal' 571 would be more appropriate, but this requires further work to better characterize the soft tissue 572 structures of the membrane. Histologically, the plates are clearly distinct from temnospondyl 573 osteoderms (Witzmann \& Soler-Gijon, 2010). Additionally, there is no modern analogue in any 574 extant anamniote tetrapod that could shed light on the formation and development of bony plates 575 in the mouth cavity. Therefore, we believe that it is not recommended to utilize the term 'dermal' 576 as it could incorrectly imply a parallel or a homology to more definitive dermal plates when there 577 are no presently known shared affinities between the two beyond the implantation in a soft 578 tissue. The term 'tooth plates,' although not inaccurate in light of the findings presented here, is 579 already used to refer to the dental structures found in lungfish (e.g., Kemp, 1977), chimaeras 580 (e.g., Ishiyama, Sasagawa, \& Akai, 1984), and ptyctodontid placoderms (e.g., Ørvig, 1985). 581 Accordingly, we believe that it is most appropriate and informative to refer to them as 'palatal 582 plates,' which indicates their position in the palatal region and their general flat profile. The 583 complementary use of the descriptor terms 'denticulate' or 'dentigerous' is acceptable but also 584 probably nonessential since the palatal plates are always known to bear at least some denticles. 585

586 Conclusion. Here we have provided histological evidence that denticles in a temnospondyl 587 amphibian (in this case, those of palatal plates) are structurally congruent with teeth based on the 
588 presence of enamel, dentine, pulp cavity with vascular canals, and associated periodontia. This

589 supports the previous work of Bystrow (1938) regarding the denticles of palatal bones of

590 Benthosuchus and provides a phylogenetic (dissorophoid vs. trematosauroid), temporal (early

591 Permian vs. early Triassic), ecological (terrestrial vs. aquatic), and positional (palatal plates vs.

592 palatal bones) bracketing on temnospondyl denticles that have been histologically sampled.

593 Given the similarity in external morphology of denticles on the palatal plates and those on the

594 palatal bones across anamniote tetrapods, it seems reasonable to conclude that this

595 characterization is likely applicable to at least the denticles of other temnospondyls, but

596 additional work across a broad taxonomic range would be necessary to confirm this. We have

597 also provided the first histological description of denticulate palatal plates in a temnospondyl,

598 which can be characterized by the dominance of primary bone matrix, the absence of a

599 cancellous interior region, the absence of secondary remodelling (via the absence of secondary

600 osteons and erosion cavities), the presence of growth marks, a high abundance of Sharpey's

601 fibers, and a low abundance of vascular channels. Although previous workers have suggested

602 that these plates were implanted in soft tissue coverings of the interpterygoid vacuities, this was

603 formulated mainly on the basis of their position in well-preserved specimens. The presence of

604 abundant Sharpey's fibers in the palatal plates provides a strong line of evidence to support their

605 positioning within a connective tissue lamina. However, a great deal of uncertainty still pertains

606 to the denticulate plates. Although we have shown that they occupied the interpterygoid vacuities

607 and likely facilitated the capture and movement of prey items, their developmental trajectory and

608 evolutionary origin remain unresolved. The most significant question that requires additional

609 work in the future is the mechanism of tooth replacement on the plates. Despite the large number

610 of plates that were sectioned, we captured only tentative evidence for replacement by origination

611 within the soft tissue and subsequent ankyloses to the plate through the identification of

612 incompletely ankylosed teeth, and only in one plate (Fig. 2B) did we capture evidence of a

613 dentine fragment located adjacent to a complete tooth that may represent an older, eroded tooth.

614 Additional considerations, such as different rates of replacement throughout ontogeny or during

615 different seasons, cannot be excluded since it is likely that all of the palatal plates of ROM 76838

616 belong to the same individual. Future work should be directed toward analyzing palatal plates of

617 other taxa to test for any associated phylogenetic differences in plate morphology (e.g., relative 
618 thickness of plates, relative abundance of Sharpey's fibers), as well as to better inform the

619 ontogeny and development (including mode of replacement) in these poorly known structures.

620

621 Acknowledgements. Thanks to Diane Scott (University of Toronto Mississauga) for assistance

622 and imaging of the specimens prior to the destructive analysis. Thanks to Aaron LeBlanc

623 (University of Alberta) and Mark MacDougall (University of Toronto Mississauga) for

624 discussions of the material. Thanks to Kevin Seymour (Royal Ontario Museum) for providing

625 specimen numbers. Thanks to William May, Richard Cifelli, and other colleagues at the Sam

626 Noble Museum of Natural History for their ongoing support of our research program on the

627 Dolese fauna. Thanks to the reviewers, Florian Witzmann and Pavel Skutschas, and to the editor,

628 Claudia Marsicano, for prompt and constructive comments that greatly improved this

629 manuscript.

630

631 References

632 - Berman DS, Berman SL. 1975. Broiliellus hektotopos sp. nov. (Temnospondyli:

633 Amphibia), Washington Formation, Dunkard Group. In: Barlow JA, Burkhammer S, eds.

634 Proceedings of the First IC White Memorial Symposium, the Age of the Dunkard.

635 Morgantown: West Virginia Geological and Economic Survey, 69-78.

636 - Berman DS, Henrici AC, Brezinski DK, Kollar AD. 2010. A new trematopid amphibian

637 (Temnospondyli: Dissorophoidea) from the Upper Pennsylvanian of Western

638 Pennsylvania: earliest record of terrestrial vertebrates responding to a warmer, drier

639 climate. Annals of Carnegie Museum 78:289-318. DOI: 10.2992/007.078.0401.

640 - Berman DS, Lucas SG. 2003. Aspidosaurus binasser (Amphibia, Temnospondyli), a new

641 species of Dissorophidae from the Lower Permian of Texas. Annals of Carnegie Museum

$642 \quad 72: 241-262$.

643 - Berman, DS. 1973. A trimerorhachid amphibian from the Upper Pennsylvanian of New

644 Mexico. Journal of Paleontology 47:932-945.

645 - Bolt JR, DeMar RE. 1983. Simultaneous tooth replacement in Euryodus and

646 Cardiocephalus (Amphibia: Microsauria). Journal of Vertebrate Paleontology 57:911-

647923. 
648 - Bossy KA, Milner AC. 1998. Order Nectridea. In: Wellnhofer, P, ed. Encyclopedia of 649 paleoherpetology, Part 1: Lepospondyli. München: Verlag Dr. Friedrich Pfeil, 73-132.

650 - Boy JA. 1972. Die Branchiosaurier (Amphibia) des saarpfälzischen Rotliegenden (Perm, 651 SW-Deutschland). Abhandlungen des Hessichen Landesamtes für Bodenforschung 65:6-

652 137.

653 - Boy JA. 1988. Über einige Vertreter der Eryopoidea (Amphibia: Temnospondyli) aus 654

655 dem europäischen Rotliegend (? höchstes Karbon - Perm) 1. Sclerocephalus.

656 Paläontologische Zeitschrift 62:107-132. DOI: 10.1007/BF02989838.

657 Boy JA. 1990. Über einige Vertreter der Eryopoidea (Amphibia: Temnospondyli) aus

658 dem europäischen Rotliegend (? höchstes Karbon-Perm) 3. Onchiodon. Paläontologische

658 Zeitschrift 64:287-312. DOI: 10.1007/BF02985720

659 Boy JA. 1995. Über die Micromelerpetontidae (Amphibia: Temnospondyli). 1.

660 Morphologie und Paläoökologie des Micromelerpeton credneri (Unter-Perm; SW-

661 Deutschland). Paläontologische Zeitschrift 69:429-457. DOI: 10.1007/BF02987805

662 Brink KS, LeBlanc ARH, Reisz RR. 2014. First record of plicidentine in Synapsida and 663 patterns of tooth root shape change in Early Permian sphenacodontians.

664 Naturwissenschaften 101:883-892. DOI: 10.1007/s00114-014-1228-5.

665 Brink KS, Reisz RR, LeBlanc ARH, Chang RS, Lee YC, Chiang CC, Huang T, Evans 666 DC. 2015. Developmental and evolutionary novelty in the serrated teeth of theropod dinosaurs. Scientific Reports 5:12338. DOI: 10.1038/srep12338.

668 Budney LA, Caldwell MW, Albino A. 2006. Tooth socket histology in the Cretaceous 669 snake Dinilysia, with a review of amniote dental attachment tissues. Journal of Vertebrate Paleontology 26:138-145. DOI: 10.1671/02724634(2006)26[138:TSHITC]2.0.CO;2

672 - Bystrow AP. 1938. Zahnstruktur der Labyrinthodonten. Acta Zoologica 19:387-425. DOI: 10.1111/j.1463-6395.1938.tb00691.x of Comparative Zoology 131:161-250. 
678 - Case EC. 1898. Studies for students: the development and geological relations of the

679 vertebrates. The Journal of Geology 6:500-523.

680 - Case EC. 1932. A collection of stegocephalians from Scurry County, Texas. University of 681 Michigan Contributions from the Museum of Paleontology 4:1-56.

682 - Clack JA, Milner AR. 2010 (for 2009). Morphology and systematics of the

683 Pennsylvanian amphibian Platyrhinops lyelli (Amphibia: Temnospondyli). Earth and

684 Environmental Science Transactions of The Royal Society of Edinburgh 100:275-295.

685 DOI: $10.1017 / \mathrm{S} 1755691010009023$.

686 - Clack JA, Witzmann F, Müller J, Snyder D. 2012. A colosteid-like early tetrapod from 687 the St. Louis Limestone (Early Carboniferous, Meramecian), St. Louis, Missouri, USA. 688 Fieldiana Life and Earth Sciences 5:17-39. DOI: 10.3158/2158-5520-5.1.17.

689 - Cox CB, Hutchinson P. 1991. Fishes and amphibians from the Late Permian Pedra de $690 \quad$ Fogo Formation of northern Brazil. Palaeontology 34:561-573.

691 - Daly E. 1994. The Amphibamidae (Amphibia: Temnospondyli), with a description of a 692 693 new genus from the Upper Pennsylvanian of Kansas. The University of Kansas Museum

694 - Damiani R, Schoch RR, Hellrung H, Werneburg R, Gastou S. 2009. The plagiosaurid 695 temnospondyl Plagiosuchus pustuliferus (Amphibia: Temnospondyli) from the Middle

696

697 Triassic of Germany: anatomy and functional morphology of the skull. Zoological Journal of the Linnean Society 155:348-73. DOI: 10.1111/j.1096-3642.2008.00444.x Damiani R, Sidor CA, Steyer JS, Smith RM, Larsson HC, Maga A, Ide O. 2006. The vertebrate fauna of the Upper Permian of Niger. V. The primitive temnospondyl Saharastega moradiensis. Journal of Vertebrate Paleontology 26:559-572. DOI:

702 10.1671/0272-4634(2006)26[559:TVFOTU]2.0.CO;2

703 (Amphibia, Temnospondyli) from the Early Triassic of Queensland and a preliminary analysis of brachyopoid relationships. Alcheringa: An Australasian Journal of Palaeontology 20:277-300. DOI: 10.1080/03115519608619472. knowledge, unanswered questions, and some directions for future research. Biological Reviews 82:49-81. DOI: 10.1111/j.1469-185X.2006.00003.x. 
709 - De Andrade, MB, Young, MT, Desojo, JB, Brusatte, SL. 2010. The evolution of extreme 710 hypercarnivory in Metriorhynchidae (Mesoeucrocodylia: Thalattosuchia) based on 711 evidence from microscopic denticle morphology. Journal of Vertebrate Paleontology 712 30:451-1465. DOI: 10.1080/02724634.2010.501442.

713 - Deban SM, Wake DB. 2000. Aquatic feeding in salamanders. In: Schwenk, K, ed. 714 Feeding: form, function and evolution in tetrapod vertebrates. San Diego: Academic $715 \quad$ Press, 65-94.

716 - Dickson JAD. 2004. Echinoderm skeletal preservation: calcite-aragonite seas and the $717 \mathrm{mg} / \mathrm{ca}$ ratio of Phanerozoic oceans. Journal of Sedimentary Research 74:355-365. DOI: $718 \quad 10.1306 / 112203740355$

719 - Eltink E, Dias EV, Dias-da-Silva S, Schultz CL, Langer MC. 2016. The cranial 720 morphology of the temnospondyl Australerpeton cosgriffi (Tetrapoda: Stereospondyli)

722 from the Middle-Late Permian of Paraná Basin and the phylogenetic relationships of

723 Rhinesuchidae. Zoological Journal of the Linnean Society 176:835-860. DOI: 10.1111/zoj.12339

725 Englehorn J, Small BJ, Huttenlocker A. 2008. A redescription of Acroplous vorax (Temnospondyli: Dvinosauria) based on new specimens from the Early Permian of Nebraska and Kansas, U.S.A. Journal of Vertebrate Paleontology 28:291-305. DOI: 10.1671/0272-4634(2008)28[291:AROAVT]2.0.CO;2.

731

732

733

734

735

- $\quad$ Fabrezi, M, Emerson, SB. 2003. Parallelism and convergence in anuran fangs. Journal of Zoology, 260:41-51. DOI: 10.1017/S0952836903003479.

737

Fröbisch NB, Olori JC, Schoch RR, Witzmann F. 2010. Amphibian development in the fossil record. Seminars in Cell \& Developmental Biology 21:424-431. DOI: 
740 - Fröbisch NB, Reisz RR. 2008. A new Lower Permian amphibamid (Dissorophoidea,

741 Temnospondyli) from the fissure fill deposits near Richards Spur, Oklahoma. Journal of

742 Vertebrate Paleontology 28:1015-1030. DOI: 10.1671/0272-4634-28.4.1015. relationships of Choristodera. Zoological Journal of the Linnean Society 124:303-353. DOI: 10.1111/j.1096-3642.1998.tb00580.x.

747 - Godfrey SJ, Fiorillo AR, Carroll RL. 1987. A newly discovered skull of the temnospondyl amphibian Dendrerpeton acadianum Owen. Canadian Journal of Earth Sciences 24:796-805. DOI: 10.1139/e87-077.

750 - Gross W. 1935. Histologische studien am aussenskelett fossiler agnathen und fische. 751 Palaeontographica 83A:1-59.

752 - Gubin YM. 1980. New Permian dissorophids of the Ural forelands. Paleontologiceskij 753 Zhurnal 1980:82-90.

754 - Hill RV. 2005. Integration of morphological data sets for phylogenetic analysis of 755 amniota: the importance of integumentary characters and increased taxonomic sampling. Systematic Biology 54:530-547. DOI: 10.1080/10635150590950326.

757 - Hook, RW. 1983. Colosteus scutellatus (Newberry): a primitive temnospondyl amphibian 758 from the Middle Pennsylvanian of Linton, Ohio. American Museum of Natural History

760 - Hook, RW. 1993. Chenoprosopus lewisi, a new cochleosaurid amphibian from 761 (Amphibia: Temnospondyli) from the Permo-Carboniferous of north-central Texas.

762 Annals of Carnegie Museum 62:273-291.

763 - Huysseune A, Sire JY, Witten PE. 2009. Evolutionary and developmental origins of the 764 vertebrate dentition. Journal of Anatomy 214:465-476. DOI: 10.1111/j.1469-

765 7580.2009.01053.x

766 Ishiyama M, Sasagawa I, Akai J. 1984. The inorganic content of pleromin in tooth plates 767 of the living holocephalan, Chimaera phantasma, consists of a crystalline calcium phosphate known as $\beta-\mathrm{Ca}_{3}\left(\mathrm{PO}_{4}\right)_{2}$ (Whitlockite). Archivum histologicum japonicum 47:89-94. DOI: 10.1679/aohc.47.89 
770 - Ivakhnenko M. 1978. Urodeles from the Triassic and Jurassic of Soviet Central Asia.

771 Palaeontologicheskiy Zhurnal 1978:84-89.

772 - Jäger P. 1997. First results of a taxonomic revision of the SE Asian Sparassidae

773 (Araneae). In: Selden PA, ed.) Proceedings of the 17th European Colloquium of Arachnology. Edinburgh: British Arachnological Society, 53-59.

775 - Jarvik E. 1954. On the visceral skeleton in Eusthenopteron with a discussion of the parasphenoid and palatoquadrate in fishes. Kunglinga Svenska Vetenskapsakademiens Handlingar 4:1-104.

778

Jarvik E. 1972. Middle and Upper Devonian porolepiformes from East Greenland with

779 special reference to Glyptolepis groenlandica n. $\mathrm{sp}$ : and a discussion on the structure of the head in the poroplepiformes. Meddelelser om Grønland 187:1-307

781 Johanson Z, Smith MM. 2005. Origin and evolution of gnathostome dentitions: a

782 question of teeth and pharyngeal denticles in placoderms. Biological Reviews 80:303-

783 345. DOI: $10.1017 / \mathrm{S} 1464793104006682$.

784

Kearney M, Rieppel O, Wood RM. 2006. An investigation into the occurrence of plicidentine in the teeth of squamate reptiles. Copeia 2006:337-350. DOI: 10.1643/0045-

786 8511(2006)2006[337:AIITOO]2.0.CO;2.

787

- Kemp A. 1977. The pattern of tooth plate formation in the Australian lungfish, Neoceratodus forsteri Krefft. Zoological Journal of the Linnean Society 60:223-258.

789 DOI: 10.1111/j.1096-3642.1977.tb01028.x Laurin M, Reisz RR. 1995. A reevaluation of early amniote phylogeny. Zoological Journal of the Linnean Society 113:165-223. DOI: 10.1111/j.1096-3642.1995.tb00932.x Lautenschlager S, Witzmann F, Werneburg I. 2016. Palate anatomy and morphofunctional aspects of interpterygoid vacuities in temnospondyl cranial evolution. The Science of Nature 103:79. DOI: 10.1007/s00114-016-1402-z Le Pennec M. 1980. The larval and post-larval hinge of some families of bivalve molluscs. Journal of the Marine Biological Association of the United Kingdom 60:601617. DOI: $10.1017 / \mathrm{S} 0025315400040297$. captorhinid reptiles: a comparative approach for understanding the origin of multiple 
800 tooth rows. Journal of Vertebrate Paleontology 35:e919928. DOI:

$801 \quad 10.1080 / 02724634.2014 .919928$

802 - Levine RP, Monroy JA, Brainerd EL. 2004. Contribution of eye retraction to swallowing

803 performance in the northern leopard frog, Rana pipiens. Journal of Experimental Biology

804 207:1361-1368. DOI: 10.1242/jeb.00885

805 - Lombard, RE, Bolt, JR. 2003. Morphology and functional implications of the mandible

806 of Whatcheeria deltae from the Late Mississippian of Iowa. In: Carrano MT, Gaudin TJ,

807 Blob RW, Wible JR, eds. Amniote paleobiology: perspectives on the evolution of

808 mammals, birds, and reptiles. Chicago: University of Chicago Press, 21-52.

809 - Long JA. 1989. A new rhizodontiform fish from the Early Carboniferous of Victoria,

810 Australia, with remarks on the phylogenetic position of the group. Journal of Vertebrate

811 Paleontology 9:1-17. DOI: 10.1080/02724634.1989.10011735.

812 - Lowenstam, HA. 1962. Magnetite in denticle capping in recent chitons (Polyplacophora).

813 Geological Society of America Bulletin 73:435-438. DOI: 10.1130/0016-

814 7606(1962)73[435:MIDCIR]2.0.CO;2.

815 - MacDougall MJ, LeBlanc ARH, Reisz RR. 2014. Plicidentine in the Early Permian

816 parareptile Colobomycter pholeter, and its phylogenetic and functional significance

817 among coeval members of the clade. PLOS ONE 9:e96559. DOI:

$818 \quad$ 10.1371/journal.pone.0096559.

819 - MacDougall MJ, Modesto SP, Reisz RR. 2016. A new reptile from the Richards Spur

820 locality, Oklahoma, U.S.A., and patterns of Early Permian parareptile diversification.

821 Journal of Vertebrate Paleontology 36:e1179641. DOI:

$822 \quad 10.1080 / 02724634.2016 .1179641$.

823 - Maddin HC, Anderson JS. 2012. Evolution of the amphibian ear with implications for

824 lissamphibian phylogeny: insight gained from the caecilian inner ear. Fieldiana Life and

825 Earth Sciences 5:59-76. DOI: 10.3158/2158-5520-5.1.59.

826 - Maliva RG. 1989. Displacive calcite syntaxial overgrowths in open marine limestones.

827 Journal of Sedimentary Research 59:397-403.

828 - Maxwell EE, Caldwell MW, Lamoureux DO, Budney LA. 2011a. Histology of tooth

829 attachment tissues and plicidentine in Varanus (Reptilia: Squamata), and a discussion of 
830 the evolution of amniote tooth attachment. Journal of Morphology 272:1170-1181. DOI:

$831 \quad$ 10.1002/jmor.10972.

832 - Maxwell EE, Caldwell MW, Lamoureux DO. 2011b. Tooth histology in the Cretaceous

833 ichthyosaur Platypterygius australis, and its significance for the conservation and

834 divergence of mineralized tooth tissues in amniotes. Journal of Morphology 272:129-

835 135. DOI: $10.1002 /$ jmor. 10898.

836 - Maxwell EE, Caldwell MW, Lamoureux DO. 2011c. The structure and phylogenetic

837 distribution of amniote plicidentine. Journal of Vertebrate Paleontology 31:553-561.

838 DOI: $10.1080 / 02724634.2011 .557117$.

839 - Mazin JM, Janvier P. 1983. L'anatomie de Lyrocephaliscus euri (Wiman), trématosaure

840 du Trias Inférieur du Spitsberg: arrière-crane, squelette axial et ceinture

$841 \quad$ scapulaire. Palaeovertebrata 13:13-31.

842 - Meunier FJ, Mondéjar-Fernández J, Goussard F, Clément G, Herbin M. 2015. Presence

843 of plicidentine in the oral teeth of the coelacanth Latimeria chalumnae Smith 1939

844 (Sarcopterygii; Actinistia). Journal of Structural Biology 190:31-37. DOI:

$845 \quad 10.1016 /$ j.jsb.2015.02.005.

846 - Milner AR, Sequeira SEK. 1993. The temnospondyl amphibians from the Viséan of east

847 Kirkton, West Lothian, Scotland. Earth and Environmental Science Transactions of The

848 Royal Society of Edinburgh 84:331-361. DOI: 10.1017/S0263593300006155

849 - Milner AR, Sequeira SEK. 1998. A cochleosaurid temnospondyl amphibian from the

850 Middle Pennsylvanian of Linton, Ohio, U.S.A. Zoological Journal of the Linnean Society

851 122:261-290. DOI: 10.1006/zjls.1997.0121.

852 - Milner AR. 1982. Small temnospondyl amphibians from the Middle Pennsylvanian of

853 Illinois. Palaeontology 25:635-664.

854 - Modesto SP, Reisz RR. 2008. New material of Colobomycter pholeter, a small

855 parareptile from the lower Permian of Oklahoma. Journal of Vertebrate Paleontology

856 28:677-684. DOI: 10.1671/0272-4634(2008)28[677:NMOCPA]2.0.CO;2.

857 - Olori JC. 2013. Ontogenetic sequence reconstruction and sequence polymorphism in

858 extinct taxa: an example using early tetrapods (Tetrapoda: Lepospondyli). Paleobiology

859 39:400-428. DOI: 10.1666/12031. 
860 - Orvig T. 1985. Histologic studies of ostracoderms, placoderms and fossil elasmobranchs

861 5. Ptyctodontid tooth plates and their bearing on holocephalan ancestry: the condition of

862 chimaerids. Zoologica Scripta 14:55-79. DOI: 10.1111/j.1463-6409.1985.tb00178.x

863 - Owen R. 1841. On the teeth of species of the genus Labyrinthodon (Mastodonsaurus of

864 Jäger) common to the German Keuper formation and the lower sandstone of Warwick

865 and Leamington. Proceedings of the Geological Society of London. London, 503-514.

866 - Patchell FC, Shine R. 1986. Hinged teeth for hard-bodied prey: a case of convergent

867 evolution between snakes and legless lizards. Journal of Zoology 208:269-275. DOI:

$868 \quad 10.1111 / \mathrm{j} .1469-7998.1986 . t b 01513 . x$

869 - Price MH, Roberts DM, McCartney BM, Jezuit E, Peifer M. 2006. Cytoskeletal dynamics

870 and cell signaling during planar polarity establishment in the Drosophila embryonic

871 denticle. Journal of Cell Science 119:403-415. DOI: 10.1242/jcs.02761.

872 - Rage J-C, Rocek Z. 1989. Redescription of Triadobatrachus massinoti (Piveteau, 1936)

873 an anuran amphibian from the early Triassic. Palaeontographica A 206:1-16.

874 - Reif W-E. 1982. Evolution of dermal skeleton and dentition in vertebrates. The odontode 875 regulation theory. Evolutionary Biology 15:287-368.

876 - Reisz RR, Schoch RR, Anderson JS. 2009. The armoured dissorophid Cacops from the

877 Early Permian of Oklahoma and the exploitation of the terrestrial realm by amphibians.

$878 \quad$ Naturwissenschaften 96:789. DOI: 10.1007/s00114-009-0533-X.

879 - Ricqlès A de, Bolt JR. 1983. Jaw growth and tooth replacement in Captorhinus aguti

880 (Reptilia: Captorhinomorpha): a morphological and histological analysis. Journal of

881 Vertebrate Paleontology 3:7-24. DOI: 10.1080/02724634.1983.10011952.

882 - Romer, AS. 1930. The Pennsylvanian tetrapods of Linton, Ohio. Bulletin of the American 883 Museum of Natural History 59:77-147.

884 - Rosowski JJ. 1992. Hearing in transitional mammals: predictions from the middle-ear 885 anatomy and hearing capabilities of extant mammals. In: Webster DB, Popper AN, Fay

886 RR, eds. The evolutionary biology of hearing. New York: Springer, 615-631. DOI:

$887 \quad 10.1007 / 978-1-4612-2784-7 \_38$.

888 - Scanlon JD, Lee MSY. 2002. Varanoid-like dentition in primitive snakes (Madtsoiidae).

889 Journal of Herpetology 36:100-106. DOI: 10.1670/0022-

890 1511(2002)036[0100:VLDIPS]2.0.CO;2. 
891 - Schoch RR, Fastnacht M, Fichter J, Keller T. 2007. Anatomy and relationships of the 892 Triassic temnospondyl Sclerothorax. Acta Palaeontologica Polonica 52:117-136.

893 - Schoch RR, Sues H-D. 2013. A new dissorophid temnospondyl from the Lower Permian 894 of north-central Texas. Comptes Rendus Palevol 12:437-445. DOI:

$895 \quad$ 10.1016/j.crpv.2013.04.002.

896 - Schoch RR, Witzmann F. 2012. Cranial morphology of the plagiosaurid Gerrothorax 897 pulcherrimus as an extreme example of evolutionary stasis. Lethaia 45:371-385. DOI:

$898 \quad$ 10.1111/j.1502-3931.2011.00290.x.

899 - Schoch RR, Witzmann FL. 2009. The temnospondyl Glanochthon from the Lower $900 \quad$ Permian Meisenheim Formation of Germany. Special Papers in Palaeontology 81:121-

901 36. DOI: $10.1111 / \mathrm{j} .1475-4983.2009 .00868 . \mathrm{x}$

902 - Schoch RR. 2006. A complete trematosaurid amphibian from the middle Triassic of 903 Germany. Journal of Vertebrate Paleontology 26:29-43. DOI: 10.1671/0272904 4634(2006)26[29:ACTAFT]2.0.CO;2.

905 - Schoch RR. 2008. A new stereospondyl from the German Middle Triassic, and the origin 906 of the Metoposauridae. Zoological Journal of the Linnean Society 152:79-113. DOI:

$907 \quad$ 10.1111/j.1096-3642.2007.00363.x.

908 - Schoch RR. 2012. Character distribution and phylogeny of the dissorophid 909 temnospondyls. Fossil Record 15:121-137. DOI: 10.1002/mmng.201200010.

910 - Schoch RR. 2013. The evolution of major temnospondyl clades: an inclusive 911 phylogenetic analysis. Journal of Systematic Palaeontology 11:673-705. DOI:

$912 \quad 10.1080 / 14772019.2012 .699006$.

913 - Schoch RR. 2014. Evolution of Functional Systems. In: Benton M, ed. Amphibian 914 evolution: the life of early land vertebrates. Hoboken: Wiley-Blackwell, 126-151. DOI:

$915 \quad 10.1002 / 9781118759127 . c h 5$

916 - Schoch, RR. 2002. The evolution of metamorphosis in temnospondyls. Lethaia 35:309-

917 327. DOI: 10.1111/j.1502-3931.2002.tb00091.x

918 - Schoch, RR. 2003. Early larval ontogeny of the Permo-Carboniferous temnospondyl

919 Sclerocephalus. Palaeontology 46:1055-1072. DOI: 10.1111/1475-4983.00333

920 - Schoch, RR. 2009. Evolution of life cycles in early amphibians. Annual Review of Earth 921 and Planetary Sciences 37:135-162. DOI: 10.1146/annurev.earth.01208.100113 
922 - Schultze H-P. 1969. Die Faltenzähne der Rhipidistiiden Crossopterygier, der Tetrapoden 923 und der Actinopterygier-Gattung Lepisosteus: nebst einer Beschreibung der Zahnstruktur

924 von Onychodus (Struniiformer Crossopterygier). Palaeontographica Italica 65:63-137.

925 - Schultze H-P. 1970. Folded teeth and the monophyletic origin of tetrapods. American 926 Museum Novitates 2408:1-10.

927 - Sequeira SEK, Milner AR. 1993. The temnospondyl amphibian Capetus from the Upper 928 Carboniferous of the Czech Republic. Palaeontology 36:657-680.

930

931

932

933

- $\quad$ Sidor CA. 2001. Simplification as a trend in synapsid cranial evolution. Evolution 55:1419-1442. DOI: 10.1554/0014-3820(2001)055[1419:SAATIS]2.0.CO;2.

935

Sigurdsen T. 2008. The otic region of Doleserpeton (Temnospondyli) and its implications 936 for the evolutionary origin of frogs. Zoological Journal of the Linnean Society 154:738-

938 - Smith JB. 2005. Heterodonty in Tyrannosaurus rex: implications for the taxonomic and systematic utility of theropod dentitions. Journal of Vertebrate Paleontology 25:865-887. DOI: 10.1671/0272-4634(2005)025[0865:HITRIF]2.0.CO;2.

941 - Steen M. 1930. 39. The British Museum collection of Amphibia from the middle coal measures of: Linton, Ohio. Journal of Zoology 100:849-891. DOI: 10.1111/j.1096-

943 3642.1930.tb01002.x

944 - Steyer JS, Damiani R, Sidor CA, O’Keefe FR, Larsson HC, Maga A, Ide O. 2006. The 945 vertebrate fauna of the Upper Permian of Niger. IV. Nigerpeton ricqlesi (Temnospondyli:

946 Cochleosauridae), and the edopoid colonization of Gondwana. Journal of Vertebrate 947 Paleontology 26:18-28. DOI: 10.1671/0272-4634(2006)26[18:TVFOTU]2.0.CO;2

948 - Sulej T. 2007. Osteology, variability, and evolution of Metoposaurus, a temnospondyl 949 from the Late Triassic of Poland. Palaeontologia Polonica 64:29-139.

950 - Sumida SS, Berman DS, Martens T. 1998. A new trematopid amphibian from the Lower 951 Permian of central Germany. Palaeontology 41:605-630. 
952 - Van Hoepen ECN. 1915. Stegocephalia of Senekal, O.F.S. Annals of the Transvaal $953 \quad$ Museum 5:125-149.

954 - Warren A, Rozefelds AC, Bull S. 2011. Tupilakosaur-like vertebrae in Bothriceps

955 australis, an Australian brachyopid stereospondyl. Journal of Vertebrate

956 Paleontology 31:738-753. DOI: $\underline{\text { 10.1080/02724634.2011.590563 }}$

957 - Warren A, Turner S. 2005. Tooth histology patterns in early tetrapods and the presence of 958 959 "dark dentine." Earth and Environmental Science Transactions of The Royal Society of Edinburgh 96:113-130. DOI: 10.1017/S0263593300001267.

960 - Warren AA, Davey L. 1992. Folded teeth in temnospondyls - a preliminary study.

961 Alcheringa: An Australasian Journal of Palaeontology 16:107-132. DOI:

962 10.1080/03115519208619036.

963 - Warren AA, Hutchinson MN. 1983. The last labyrinthodont? A new brachyopoid 964 (Amphibia, Temnospondyli) from the Early Jurassic Evergreen Formation of

965 Queensland, Australia. Philosophical Transactions of the Royal Society B: Biological 966 Sciences 303:1-62. DOI: 10.1098/rstb.1983.0080.

967 - Welles SP, Cosgriff, J. 1965. Revision of the labyrinthodont family Capitosauridae; and a 968 description of Parotosaurus peabodyi, n. sp. from the Wupatki member of the Moenkopi

969 Formation of Northern Arizona. University of California Publications in Geological $970 \quad$ Sciences 54:1-148.

971 - Witzmann F, Schoch RR. 2006 (for 2005). Skeletal development of the temnospondyl 972

973 Acanthostomatops vorax from the Lower Permian Döhlen Basin of Saxony. Earth and Environmental Science Transactions of The Royal Society of Edinburgh 96:365-385.

974 DOI: $10.1017 / \mathrm{S} 0263593300001358$.

975 - Witzmann F, Soler-Gijón R. 2010. The bone histology of osteoderms in temnospondyl amphibians and in the chroniosuchian Bystrowiella. Acta Zoologica 91:96-114. DOI:

977 10.1111/j.1463-6395.2008.00385.x.

- Witzmann F, Werneburg I. 2017. The palatal interpterygoid vacuities of temnospondyls and the implications for the associated eye- and jaw musculature. The Anatomical Record 300:1240-1269. DOI: 10.1002/ar.23582.

981 - Witzmann F. 2004. The external gills of Palaeozoic amphibians. Neues Jahrbuch fur 982 Geologie und Palaontologie-Abhandlungen 232:375-401. 
983 - Witzmann F. 2005. Hyobranchial and postcranial ontogeny of the temnospondyl

984 Onchiodon labyrinthicus (Geinitz, 1861) from Niederhäslich (Dohlen Basin, Autunian,

985 Saxony). Paläontologische Zeitschrift 79:479-492. DOI: 10.1007/BF02988374.

986 Witzmann F. 2006. Developmental patterns and ossification sequence in the Permo-

987 Carboniferous temnospondyl Archegosaurus decheni (Saar-Nahe Basin, Germany).

988 Journal of Vertebrate Paleontology 26:7-17. DOI: 10.1671/0272-

989 4634(2006)26[7:DPAOSI]2.0.CO;2.

990

Witzmann F. 2013. Phylogenetic patterns of character evolution in the hyobranchial

991

992 apparatus of early tetrapods. Earth and Environmental Science Transactions of the Royal Society of Edinburgh 104:145-167. DOI: 10.1017/S1755691013000480

993

994

Figure \& Table Captions

995

996

Figure 1. The external morphology of the palatal plates in the sampled specimen (ROM

997 76838) and Pasawioops. (A-C) images of the sampled block of palatal plates (ROM 76838) from various views; (D) an image of the dorsal surface of the palatal plates; (E) an enlarged view of the denticulate surface of the plate; (F) an individual tooth on the plate, showing fluting; (E) an SEM image of the block from which the plates were isolated; (F) enlarged SEM image of the denticulate surface of the plate; $(\mathrm{G})$ an SEM image of a single tooth; $(\mathrm{H})$ an image of the palatal view of the holotype of Pasawioops (OMNH 73019); (I) An enlarged view of the palatal plates;

1003 (J) an enlarged view of the dentition on the palatal plates showing the orientation of the

1004 dentition.

1005

1006

Figure 2. Histological characterization of two denticulate plates considered to be representative of the sample (ROM 76838). (A-D) TS01135; (E-G) TS01140. (A) A schematic representation of TS01135 to show relative location of the histological features; (B) enlarged view of the crown of the tooth; $(\mathrm{C})$ enlarged view of a fragment of dentine belonging to a

1010 previous generation of teeth at this position; (D) enlarged view of the Sharpey's fibers that are 1011 embedded with in the plate; (E) enlarged view showing possible plicidentine at the junction 1012 between the tooth and plate; (F) enlarged view Sharpey's fibers imaged under cross-polarized 1013 light; (G) the same view as (D) in cross-polarized light. Scale bar $=500 \mu \mathrm{m}$. 
1015 Figure 3. Histological sections showing the variation in palatal plate anatomy of ROM

1016 76838. (A)TS01115; (B) TS01136; (C) TS01137; (D) TS01142; (E) TS01134; (F) TS01168; (G)

1017 TS00141; (H) TS01147. Scale bar $=500 \mu \mathrm{m}$.

1018

1019 Figure 4. Histological sections showing incomplete ankylosis of the teeth to the palatal

1020 plates of ROM 76838. (A) TS01142 showing incomplete ankylosis of a tooth to the plate; (B)

1021 close-up of the attachment site of the same tooth; (C) TS 01134 showing incomplete ankylosis of

1022 a tooth to the plate; (D) close-up of the attachment site of the same tooth; (E-F) incomplete

1023 ankylosis in TS01145and TS01167. Scale bar $=500 \mu \mathrm{m}$.

1024

1025 Figure 5. A schematic diagram featuring a cross section of a dissorophid skull with the

1026 position of the denticulate palatal plates in the interpterygoid vacuities. (A) representation of

1027 the palatal plates in the oral epithelium covering the interpterygoid vacuity in a resting state; (B)

1028 representation of the plates during ventral expansion of the epithelium (e.g., during feeding).

1029

1030 Figure 6. Results of the literature survey on the occurrence of palatal plates in

1031 temnospondyl amphibians. Phylogeny is modified from Schoch (2013). Red lines and asterisks

1032 indicate a documented occurrence of the plates; corresponding references are listed in Table 1.

1033

1034 Table 1. Listing of documented occurrences of denticulate palatal plates recovered from

1035 the literature review conducted as a part of this study. All taxa with a superscript number are

1036 tentative observations that were not included in the phylogeny and are briefly described here.

1037 This list should not considered to be exhaustive, as palatal plates may occur in other taxa

1038 unknown to us for a number of reasons, including, but not limited to: inaccessibility of

1039 publications, previous misidentification of plates as other ossifications, and loss or removal

1040 during preparation without documentation. (1) Only a shelf similar to taxa in which palatal plates

1041 are known was identified; (2) a relatively large denticulate plate on the left ectopterygoid is

1042 present, but it is not clear whether this is the natural position; (3) several denticulate plates are

1043 noted between the mandible and the displaced clavicle; the author suggested them to be branchial

1044 plates but also noted them to be unusually wide; (4) isolated denticulate plates were identified in 
1045 the interpterygoid region but it could not determined whether they covered the vacuities or the 1046 parasphenoid; (5) a number of 'scales' were found in the intermandibular region near the ramus 1047 and the cultriform process, but most were removed during preparation; (6) this observation is 1048 considered tentative only because the authors of this paper were unable to access the original 1049 publication; (7) a few small plates with "dots" that probably represent broken denticles are found 1050 on the parasphenoid; (8) a large number of variably sized plates in the anterior portion of the 1051 vacuity were identified as scleral plates; more plates in the posterior half, as well as denticles, 1052 may have been removed during preparation based on photos of the specimen; (9) a number of 1053 small denticulate plates are cemented near the base of the cultriform process and were paralleled 1054 to those of Chenoprosopus; (10) two isolated patches of denticles are found on the parasphenoid 1055 that were suggested to be fragments of the overlying sheet that would have covered the basal 1056 plate. 


\section{Figure 1}

The external morphology of the palatal plates in the sampled specimen (ROM 76838) and Pasawioops.

(A-C) images of the sampled block of palatal plates (ROM 76838) from various views; (D) an image of the dorsal surface of the palatal plates; $(E)$ an enlarged view of the denticulate surface of the plate; (F) an individual tooth on the plate, showing fluting; $(E)$ an SEM image of the block from which the plates were isolated; (F) enlarged SEM image of the denticulate surface of the plate; $(\mathrm{G})$ an SEM image of a single tooth; $(\mathrm{H})$ an image of the palatal view of the holotype of Pasawioops (OMNH 73019); (I) An enlarged view of the palatal plates; (J) an enlarged view of the dentition on the palatal plates showing the orientation of the dentition. 

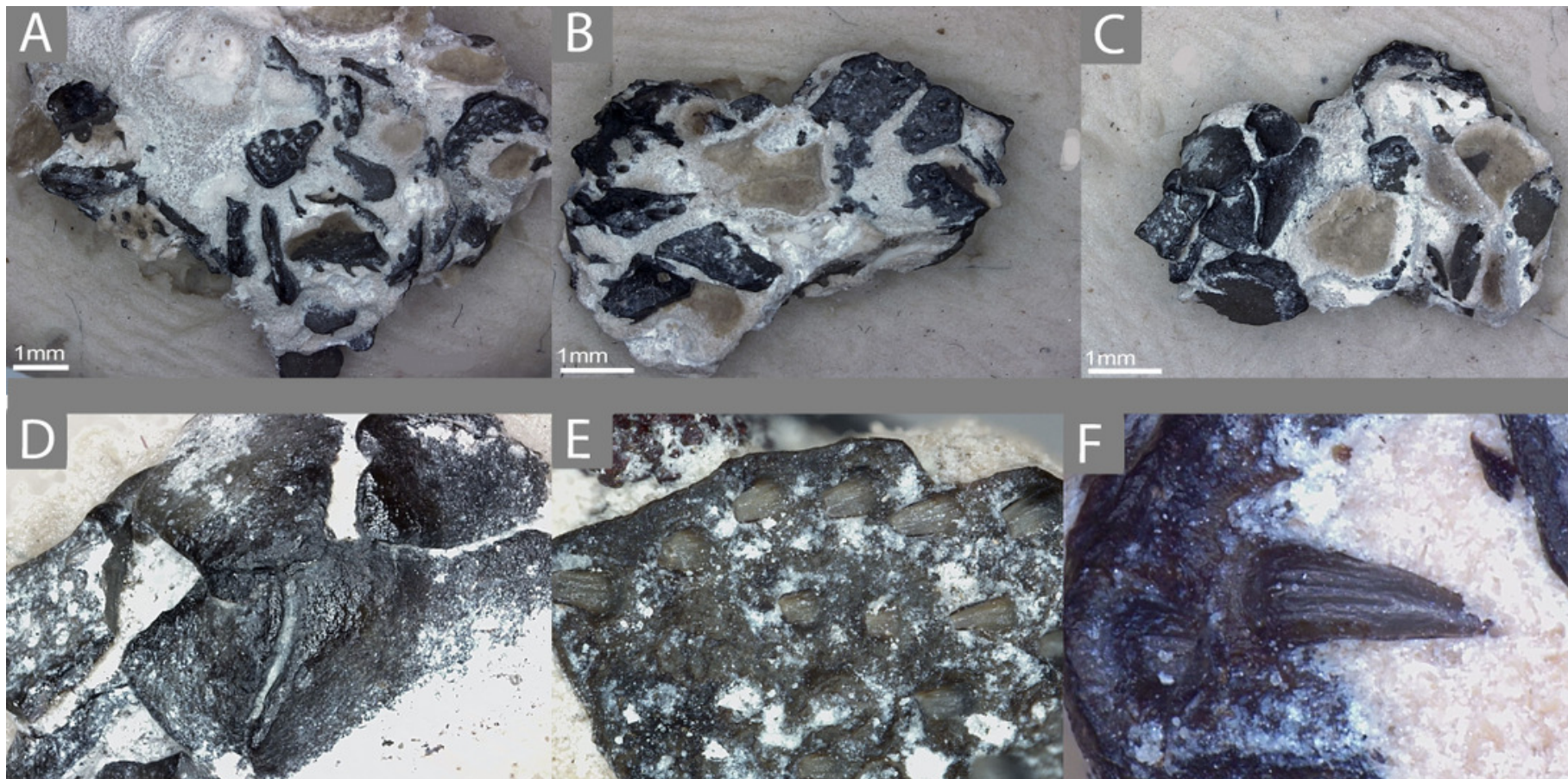

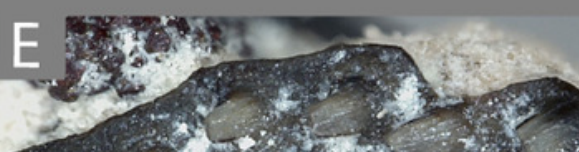


Nowis
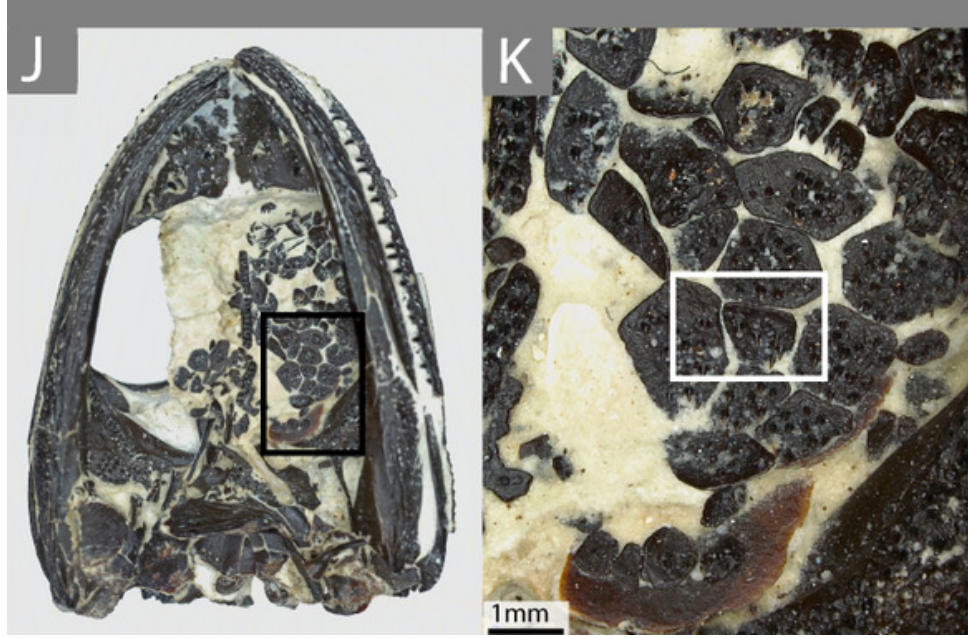
$250 \mathrm{um}$
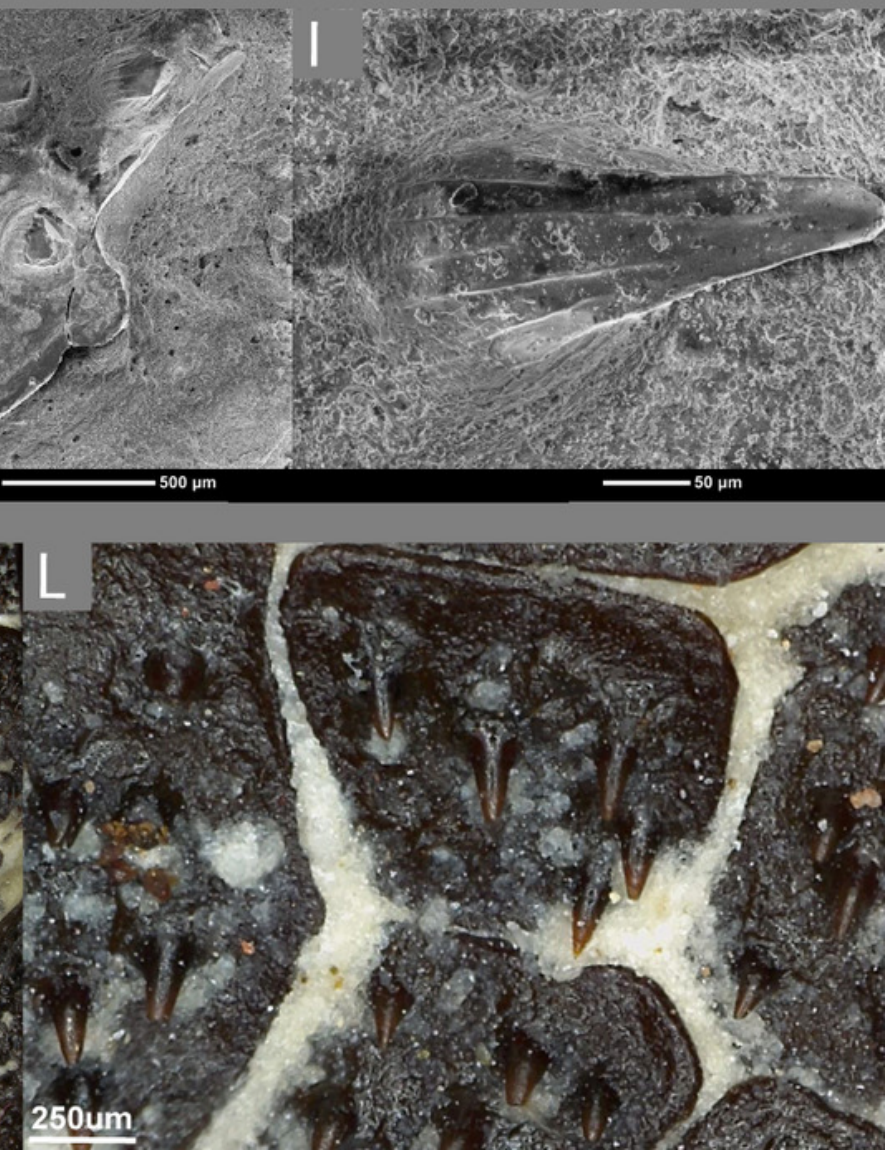


\section{Figure 2}

Histological characterization of two denticulate plates considered to be representative of the sample (ROM 76838).

(A-D) TS01135; (E-G) TS01140. (A) A schematic representation of TS01135 to show relative location of the histological features; (B) enlarged view of the crown of the tooth; (C) enlarged view of a fragment of dentine belonging to a previous generation of teeth at this position; (D) enlarged view of the Sharpey's fibers that are embedded with in the plate; (E) enlarged view showing possible plicidentine at the junction between the tooth and plate; (F) enlarged view Sharpey's fibers imaged under cross-polarized light; (G) the same view as (D) in crosspolarized light. Scale bar $=500 \mu \mathrm{m}$. 

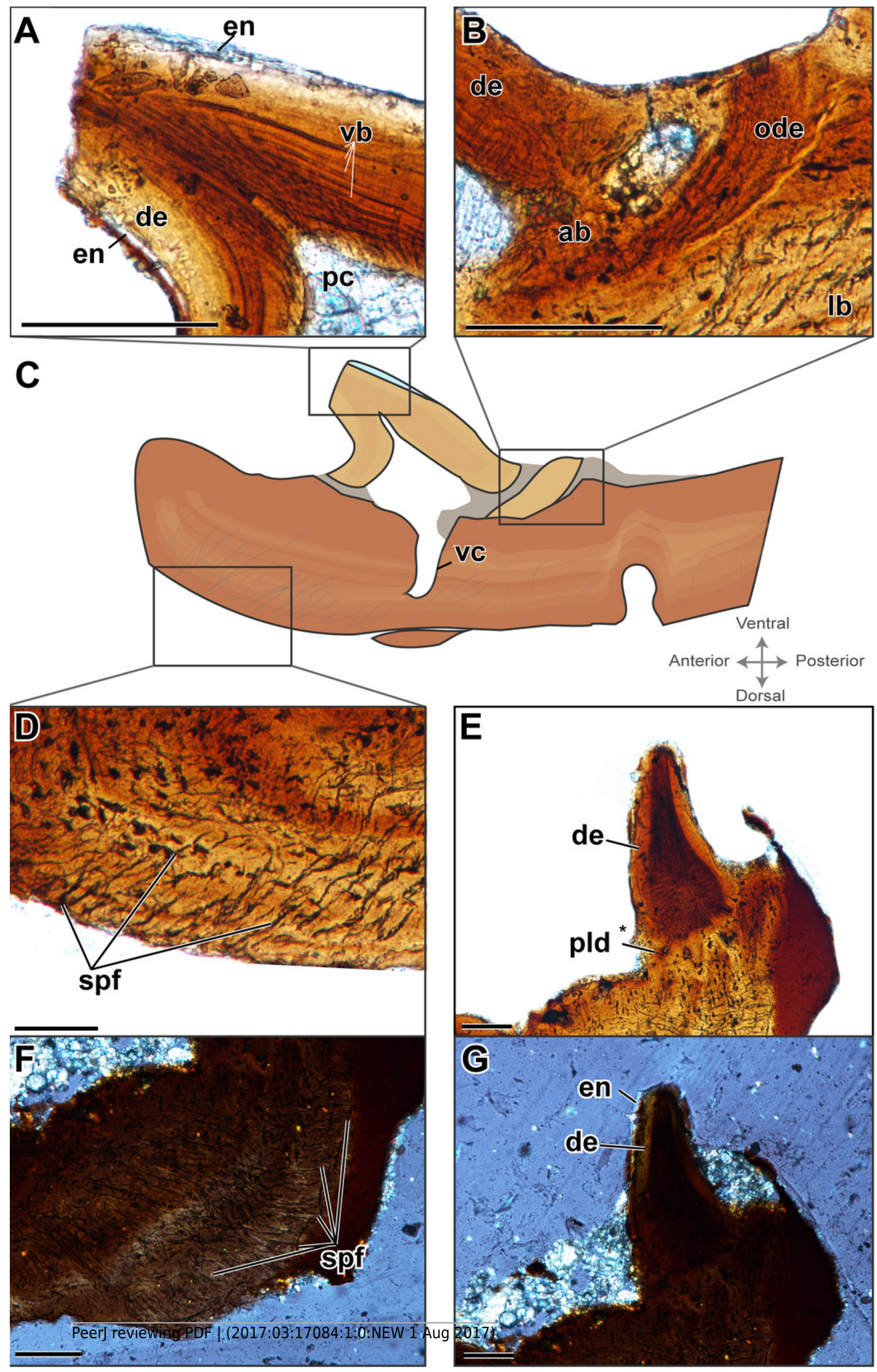
Figure 3

Histological sections showing the variation in palatal plate anatomy of ROM 76838. Scale bar $=500 \mu \mathrm{m}$.
(A)TS01115; (B) TS01136;
(C) TS01137;
(D) TS01142;
(E) TS01134; (F) TS01168; (G) TS00141; (H) TS01147.

A
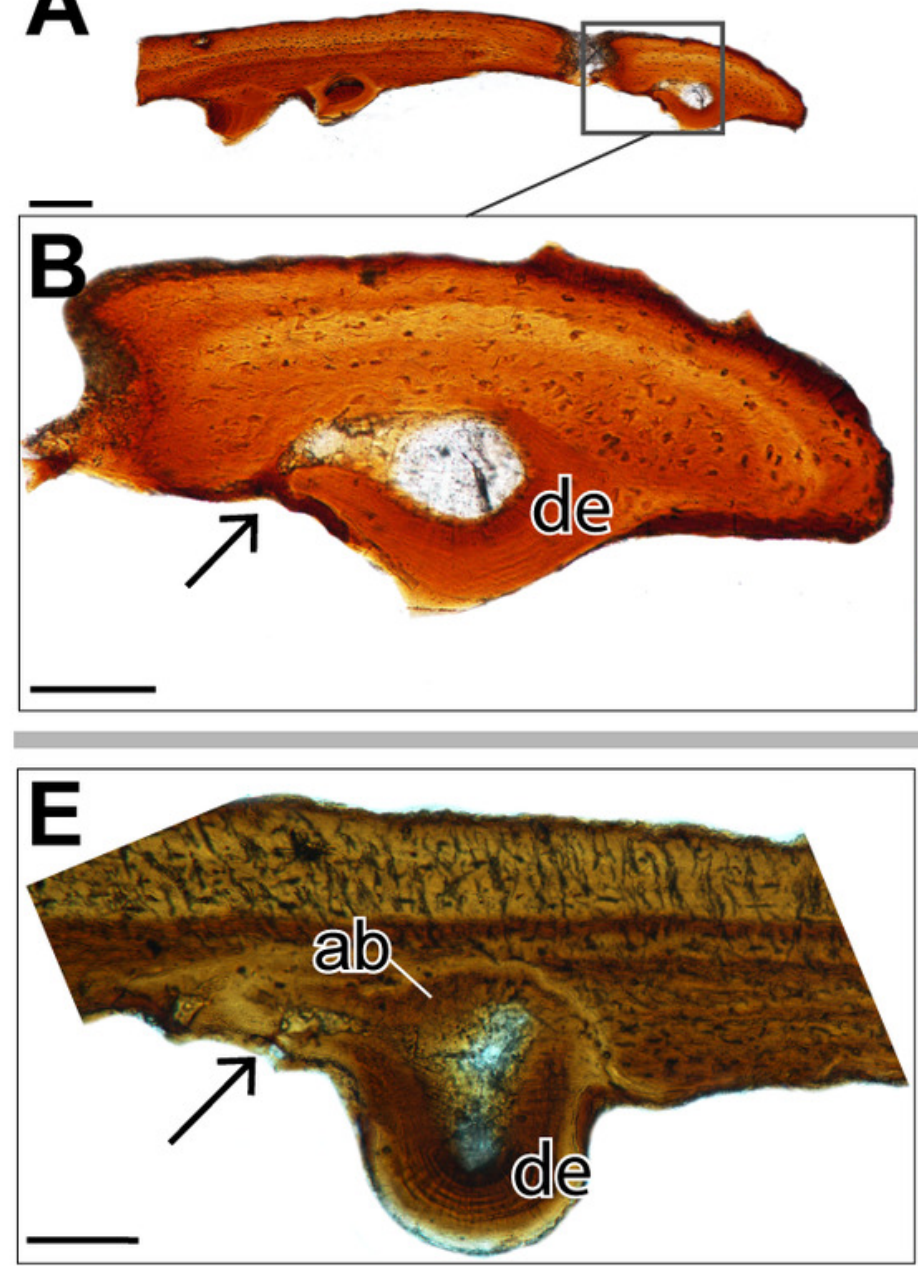

C
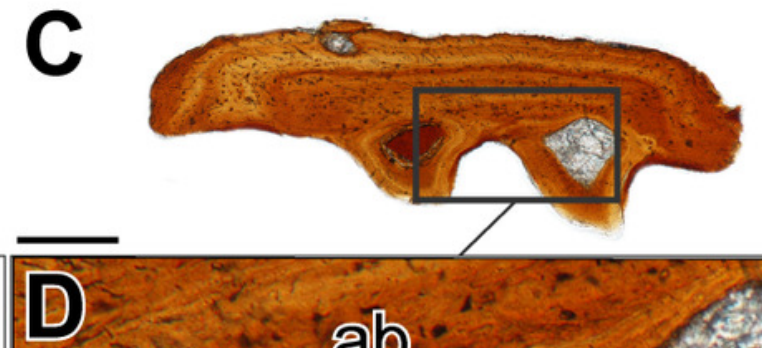

áb-
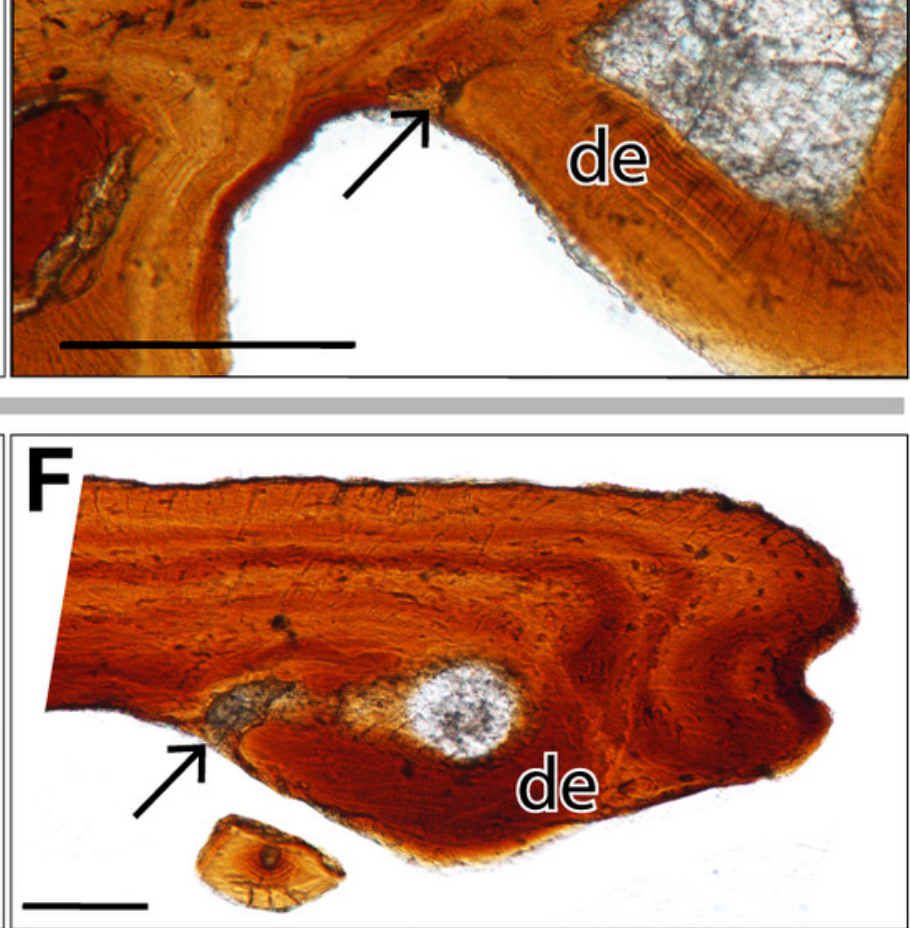


\section{Figure 4}

Histological sections showing incomplete ankylosis of the teeth to the palatal plates of ROM 76838.

(A) TS01142 showing incomplete ankylosis of a tooth to the plate; (B) close-up of the attachment site of the same tooth; (C) TS 01134 showing incomplete ankylosis of a tooth to the plate; (D) close-up of the attachment site of the same tooth; (E-F) incomplete ankylosis in TS01145and TS01167. Scale bar $=500 \mu \mathrm{m}$. 


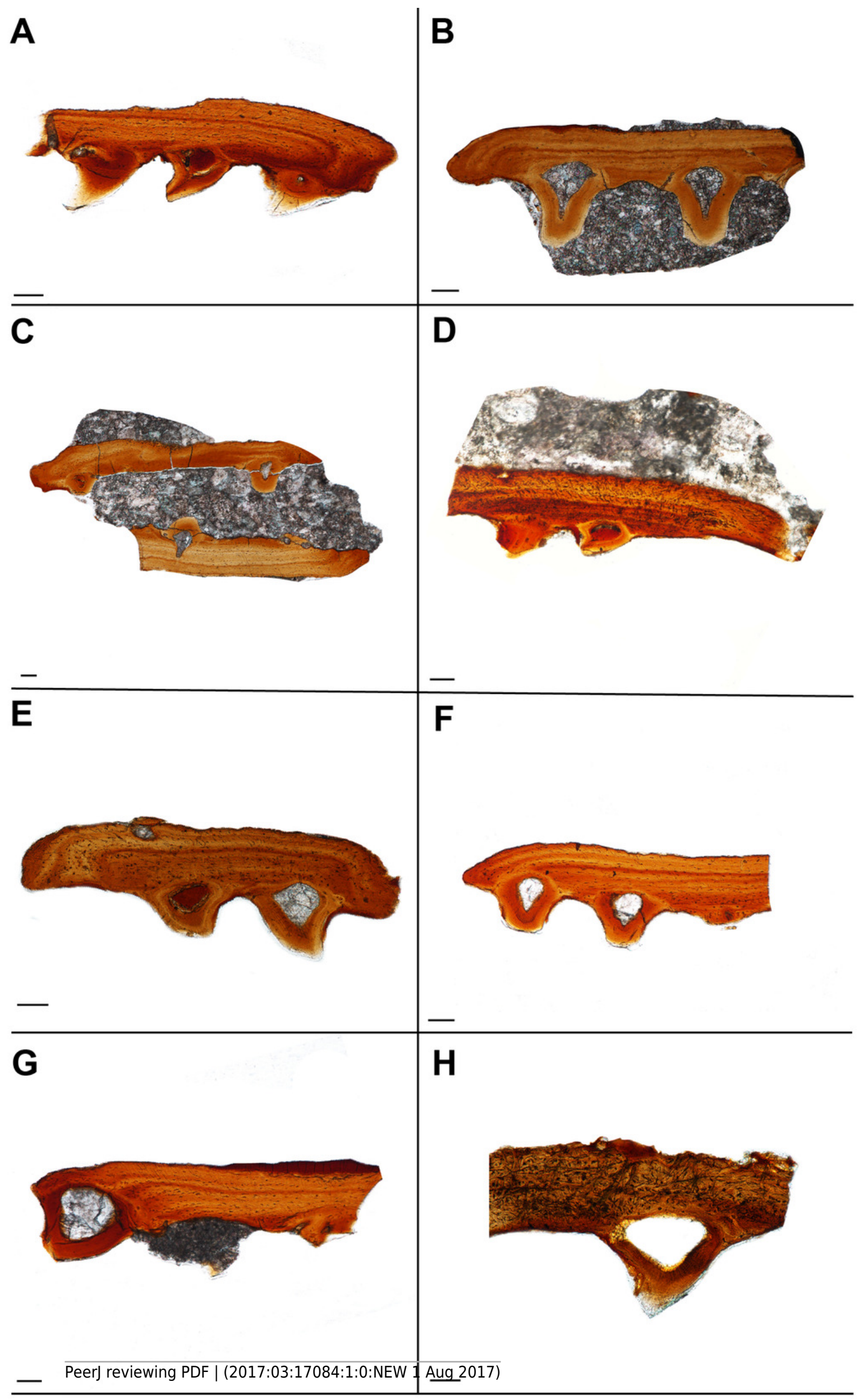




\section{Figure 5}

A schematic diagram featuring a cross section of a dissorophid skull with the position of the denticulate palatal plates in the interpterygoid vacuities.

(A) representation of the palatal plates in the oral epithelium covering the interpterygoid vacuity in a resting state; (B) representation of the plates during ventral expansion of the epithelium (e.g., during feeding).
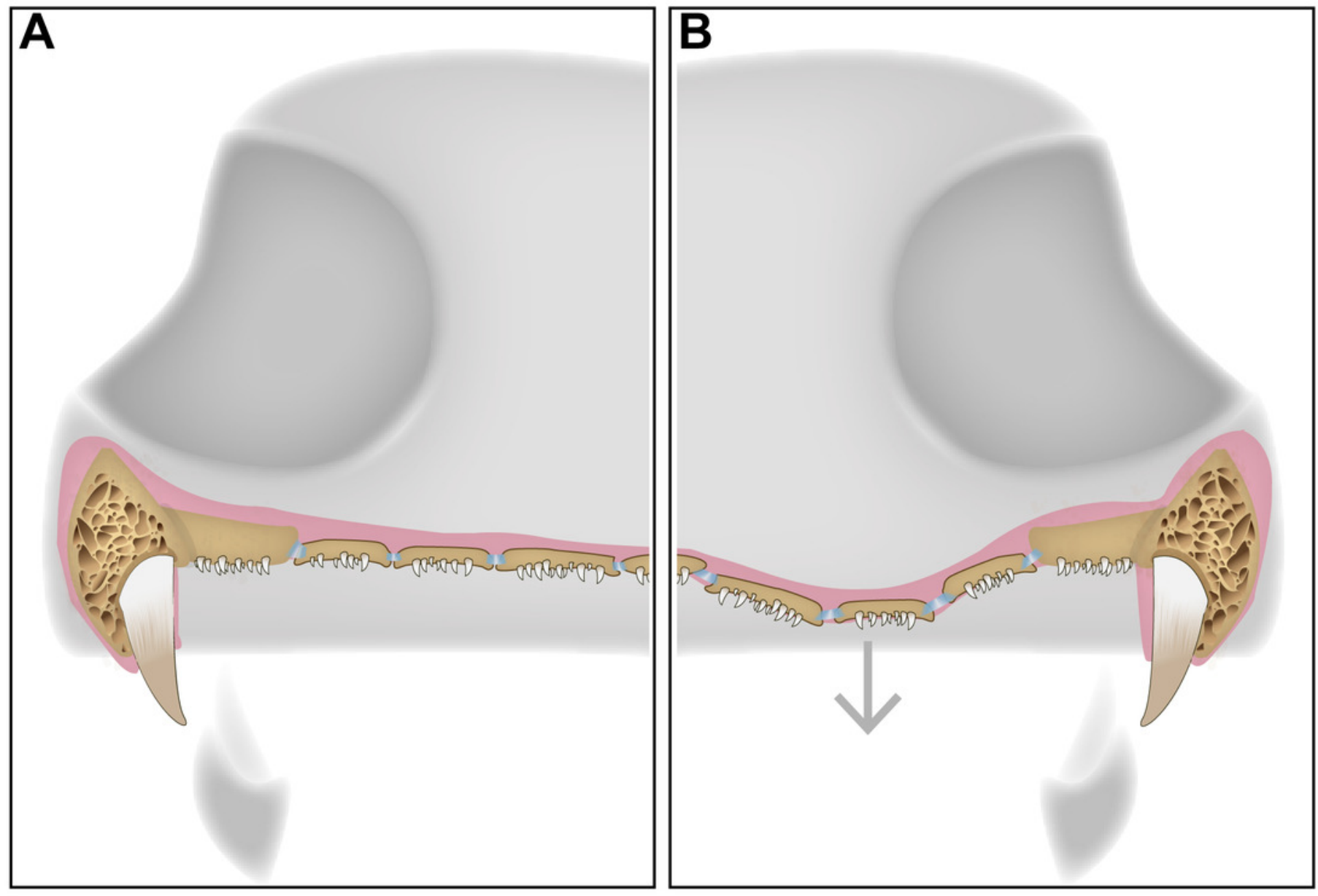


\section{Figure 6}

Results of the literature survey on the occurrence of palatal plates in temnospondyl amphibians.

Phylogeny is modified from Schoch (2013). Red lines and asterisks indicate a documented occurrence of the plates; corresponding references are listed in Table 1. 


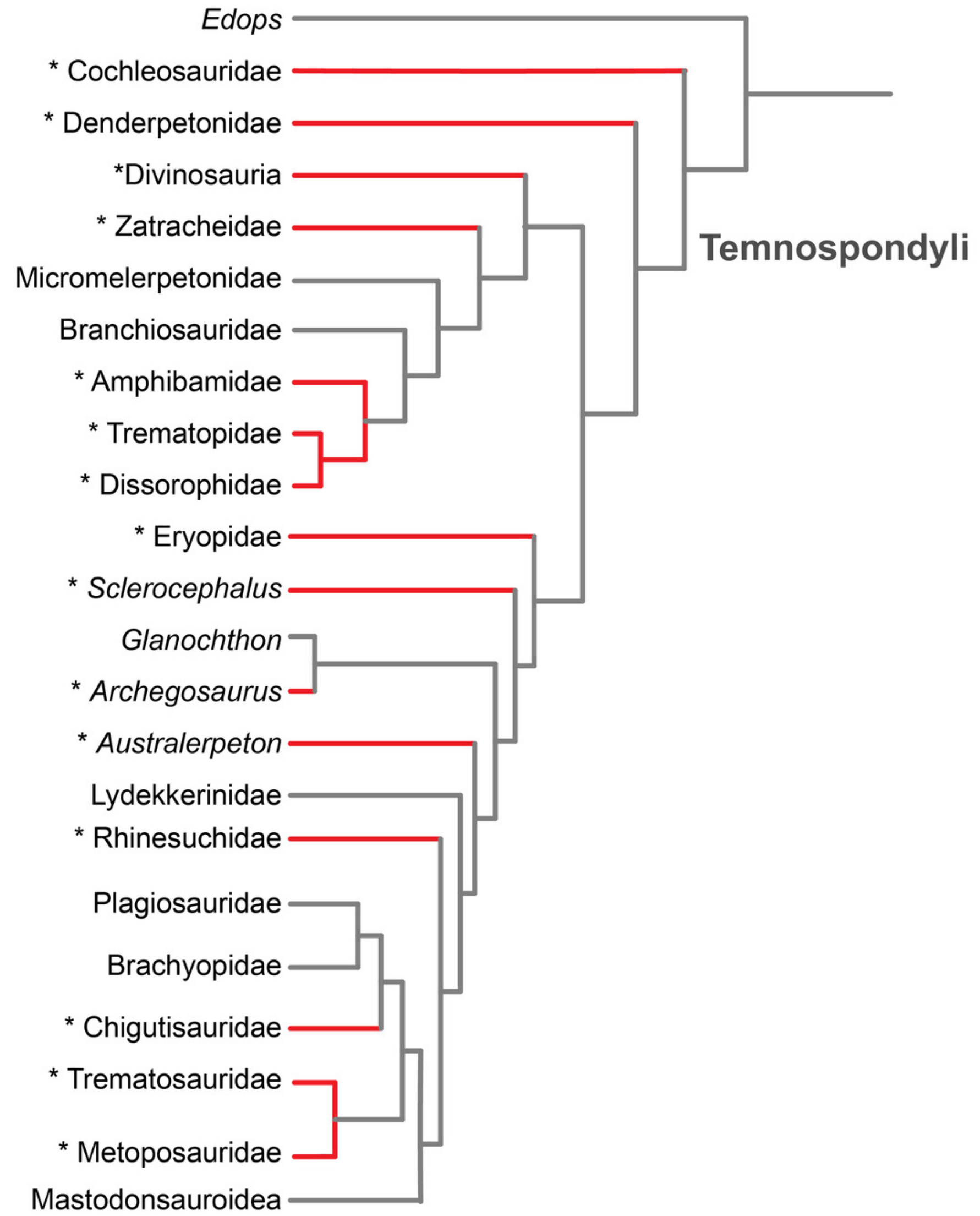




\section{Table $\mathbf{1}$ (on next page)}

Listing of documented occurrences of denticulate palatal plates recovered from the literature review conducted as a part of this study.

All taxa with a superscript number are tentative observations that were not included in the phylogeny and are briefly described here. (1) The authors only identified a shelf similar to taxa in which palatal plates are known; (2) a relatively large denticulate plate on the left ectopterygoid is present, but it is not clear whether this is the natural position; (3) several denticulate plates are noted between the mandible and the displaced clavicle; Schoch (2008) suggested them to be branchial plates but also noted them to be unusually wide; (4) the authors identified isolated denticulate plates in the interpterygoid region but could not determine whether they covered the vacuities or the parasphenoid; (5) a number of 'scales' were found in the intermandibular region near the ramus and the cultriform process, but most were removed during preparation; (6) this observation is considered tentative only because the authors were unable to access the original publication; (7) a few small plates with "dots" that probably represent broken denticles are found on the parasphenoid; (8) a large number of variably sized plates in the anterior portion of the vacuity were identified as scleral plates; more plates in the posterior half, as well as denticles, may have been removed during preparation based on photos of the specimen; (9) a number of small denticulate plates are cemented near the base of the cultriform process and were paralleled to those of Chenoprosopus; (10) two isolated patches of denticles are found on the parasphenoid that were suggested to be fragments of the overlying sheet that would have covered the basal plate. 


\begin{tabular}{|c|c|}
\hline Taxon & Reference \\
\hline Acanthostomatops vorax & Witzmann \& Schoch (2006:369, fig. 4) \\
\hline Adamanterpeton ohioensis & Milner \& Sequeira (1998:278, fig. 2) \\
\hline Archegosaurus decheni & Witzmann $(2006: 148$, figs. 8,17$)$ \\
\hline Aspidosaurus binasser & Berman \& Lucas (2003:250, fig. 3$)$ \\
\hline Balanerpeton woodi & Milner \& Sequeira (1993:339) \\
\hline "Broiliellus" hektotopos & Berman \& Berman (1975:72-73, fig. 2) \\
\hline Cacops morrisi & Reisz, Schoch, \& Anderson (2009:793, fig. 3) \\
\hline Colosteid-like tetrapod & Clack et al. (2012:22, fig. 2A) \\
\hline Denderpeton acadianum & Godfrey, Fiorillo, \& Carroll (1987:800, fig. 1D) \\
\hline Dissorophus sp. & BMG pers. obs. \\
\hline Eoscopus locklardi & Daly $(1994: 8)$ \\
\hline Erpetosaurus radiatus & Romer (1930:110, fig. 15) \\
\hline Fedexia striegeli & Berman et al. (2010:309; fig. 9B) \\
\hline Kamacops acervalis & Gubin (1980:83-88) \\
\hline Metoposaurus krasiejowensis & Sulej (2007:56-60, fig. 2E) \\
\hline Onchiodon labyrinthicus & Witzmann $(2005: 481)$ \\
\hline Pasawioops mayi & Fröbisch \& Reisz (2008:1020, fig. 3) \\
\hline Phonerpeton pricei & Witzmann \& Werneburg (2017:8, fig. 4B) \\
\hline \multirow[t]{2}{*}{ Platyrhinops lyelli } & Carroll (1964:231-233, fig. 21) \\
\hline & Clack \& Milner (2010:288, figs.2c, 6a, 7a) \\
\hline Prionosuchus plummeri & Cox \& Hutchinson (1991:568) \\
\hline \multirow[t]{3}{*}{ Sclerocephalus haeuseri } & Boy (1988:116, abb. 4C) \\
\hline & Schoch \& Witzmann (2009: 148, figs. 6B, E) \\
\hline & Witzmann \& Werneburg (2017:8, fig. 4A) \\
\hline Sclerothorax hypselonotus & Schoch et al. (2007:122, fig. 3C) \\
\hline Siderops kuehli & Warren \& Hutchinson (1983:18) \\
\hline \multirow[t]{2}{*}{ Stegops divaricata } & Steen (1930:862, pl. II, fig. 2) \\
\hline & Romer (1930:115) \\
\hline Tambachia trogallas & Sumida, Berman, \& Martens (1998:617, figs. 6-7) \\
\hline Trematolestes hagdorni & Schoch $(2006: 34$, figs. 2C, 4B) \\
\hline Uranocentrodon senekalensis & van Hoepen (1915:134) \\
\hline${ }^{1}$ Australerpeton cosgriffii & Eltink et al. (2016:14) \\
\hline${ }^{2}$ Bothriceps australis & Warren, Rozefelds, \& Bull (2011:743, fig. 3) \\
\hline${ }^{3}$ Callistomordax kugleri & Schoch $(2008: 91)$ \\
\hline${ }^{4}$ Capetus palustris & Sequeira \& Milner (1993:650) \\
\hline${ }^{5}$ Chenoprosopus lewisii & Hook (1993:284, fig. 2A) \\
\hline${ }^{6}$ Glyptolepis groenlandica & Jarvik (1972: fig. 30) as referenced in Clack et al. (2012) \\
\hline${ }^{7}$ Lyrocephaliscus euri & Mazin \& Janvier (1983:19, fig. 1) \\
\hline 8"Metoposaurus" bakeri & Case (1932: pl. 2, fig. 5) \\
\hline${ }^{9}$ Nigerpeton ricqlesi & Steyer et al. (2006:23, fig. 2B) \\
\hline${ }^{10}$ Saharastega moradiensis & Damiani et al. (2006:567, fig. 3B) \\
\hline
\end{tabular}


2 Table 1. Listing of documented occurrences of denticulate palatal plates recovered from 3 the literature review conducted as a part of this study. All taxa with a superscript number are

4 tentative observations that were not included in the phylogeny and are briefly described here. (1)

5 The authors only identified a shelf similar to taxa in which palatal plates are known; (2) a

6 relatively large denticulate plate on the left ectopterygoid is present, but it is not clear whether

7 this is the natural position; (3) several denticulate plates are noted between the mandible and the

8 displaced clavicle; Schoch (2008) suggested them to be branchial plates but also noted them to

9 be unusually wide; (4) the authors identified isolated denticulate plates in the interpterygoid

10 region but could not determine whether they covered the vacuities or the parasphenoid; (5) a

11 number of 'scales' were found in the intermandibular region near the ramus and the cultriform

12 process, but most were removed during preparation; (6) this observation is considered tentative

13 only because the authors were unable to access the original publication; (7) a few small plates

14 with "dots" that probably represent broken denticles are found on the parasphenoid; (8) a large number of variably sized plates in the anterior portion of the vacuity were identified as scleral plates; more plates in the posterior half, as well as denticles, may have been removed during preparation based on photos of the specimen; (9) a number of small denticulate plates are cemented near the base of the cultriform process and were paralleled to those of Chenoprosopus; (10) two isolated patches of denticles are found on the parasphenoid that were suggested to be fragments of the overlying sheet that would have covered the basal plate. 